CHAPTER ONE

\title{
THE ACADEMIC DISCOURSE: POLITICAL ORDER AND CORRUPTION IN AFRICA
}

\begin{abstract}
Hence the general feeling of helplessness in the face of an infernal mechanism. And hence this hypothesis, which is also a risk: the development of movements of a 'puritanical' tendency, intended to bring about a reform of public morals [...] may be among the ultimate means, in absence of an improbable selfreformation of the political elites, to attempt to change the present course of affairs. Any 'anti-corruption' policy must face up to these realities. ${ }^{1}$

Even more insidious is in my opinion what might be called the calculated violence of neglect: that is, the deliberate failure of governments and state offcials to carry out their duties in order to benefit from the ensuing disorder and distress. ${ }^{2}$
\end{abstract}

\section{Introduction}

In one of the first systematic studies of corruption in post-independence African countries, McMullan comes to the conclusion that it "is part of the general conflict between the aims and the methods of the government and the society which is being governed that the subjective attitude of many officials in these countries should not be in harmony with their objective roles" (McMullan 1961: 194), with "the colonial regime [being] the obvious historical source of the conflict between the government and the society" (McMullan 1961: 199). Although the vocabulary may sound slightly dated, this analysis is echoed in many of the most noted and provocative contributions to political order in Africa of recent years. The seminal study by Chabal and Daloz on the political instrumentalisation of disorder in African states paints a picture of

a colonial civil service which sought to devise pragmatic ways of adapting the imperial directives to the administration of its subjects rather than a method of inculculating new political and governmental habits. [...] Moreover, the colonial experience showed how a 'modern' bureaucracy could be

1 See Olivier de Sardan 1999: 48.

2 See Chabal 2009: 153 . 
both arbitrary and personalized—characteristics which were infinitely more compatible with existing African practices than the original Western model (Chabal/Daloz 1999: 12). ${ }^{3}$

They discuss in detail the processes in which contemporary African postcolonial states 4 have appropriated, adapted, moulded and shaped their histories and tradition, concluding

that, in most African countries, the state is no more than a décor, a pseudoWestern façade masking the realities of deeply personalized political relations. There may well appear to be a relative institutionalization of the main state structures but such bodies are largely devoid of authority. [...] In Black Africa [state] legitimacy is firmly embedded in the patrimonial practices of patrons and their networks (Chabal/Daloz 1999: 16). ${ }^{5}$

Judging from these seminal theoretical contributions set nearly four decades and several development paradigms ${ }^{6}$ apart, several observations can be made. First of all, rather intriguingly, it seems that the essence of key hypotheses on the causes and consequences of corruption has not fundamentally changed in four decades, namely that personalised and particularistic (in McMullan's terminology: 'subjective') imperatives govern public institutions. This is surprising, given not just the time that has elapsed since then, but the fact that the geo-political and economic realities of developing countries (and indeed of industrialised countries) have undergone fundamental structural transformations in the wake of the end of the Cold War and processes of communicative, financial and economic globalisation. ${ }^{7}$ And in this context, the amount of targeted and conditional foreign aid that has been directed at African countries to foster the rule of law and strong public institutions also merits attention.

3 See also Ekeh 1975 for a seminal contribution on colonialism and the 'two publics' in Africa.

4 An evocative interpretation of post-colonial states is rendered by Mbembe, who also emphasises their originality: "In my mind, the notion of the 'postcolony' refers to a timescape which is simultaneously in the process of being formed and of being dissolved through a movement that brings both the 'being formed' and the 'being dissolved' into collision. The term 'postcolony' indicates my desire to take very seriously the intrinsic qualities and power of 'contemporaneousness' while firmly keeping in mind the fact that the present itself is a concatenation of multiple temporalities. Because of the entanglement of these multiple temporalities, Africa is evolving in multiple and overlapping directions simultaneously" (Mbembe 2002: 4).

5 For a seminal contribution on the cultural logic and moral matrix underlying the legitimisation strategies of patronage relations see Schatzberg 2001.

6 See Pieterse 2001 for an excellent overview and discussion of development paradigms of the last five decades.

7 For key analyses see Rosenau 2003. 
Second and more fundamentally, these quotes indicate that the exploration and conceptualisation of corruption oscillates around the relationship between state and society. This is what makes the analysis of corruption so fruitful, that it is located in the very vertebrae of reflections on contemporary state-society relationships. More precisely, the analysis of corruption pierces the underbelly of state/society relations: its very naming necessarily indicates a challenge to the norm-setting primacy of the public sphere, and the dominance of legal and bureaucratic rationalities in a classic Weberian sense. In this vein, it can be argued that structural factors, such as the configuration ${ }^{8}$ of the post-colonial state, or the effects of privatisation and pluralisation of the public domain, are key to understanding corruption; or rather, corruption is key to understanding the fields ${ }^{9}$ of power and agency shaped by such structural factors. Simultaneously, the importance of social agency also shines through, inferred by the 'subjective' and the personalised ties that actors utilise and operationalise. And, not least, there seems to be a cultural dimension to corruption, particular value systems and morals that underpin and legitimise 'corrupt' structures and social practices. A 'culture of corruption' may be on the surface a function of a bloated bureaucracy and greedy, self-serving public officials; but equally the social mechanisms and legitimising processes of corrupt practices (and resistance) by the actors themselves, and their interaction with the systemic and structural factors are in need of illumination.

A final preliminary comment needs to be made at this point, namely the key importance of the state as an analytical reference point in the study of corruption. This is a very basic premise: only with the emergence modern state's constitutive feature of a separated public (state) and private (society) sphere 'corruption' in the modern sense became conceivable: namely as an act or behaviour which crosses the boundary between the public

8 The term 'configuration' reverberates Elias (1976-1982) conceptualisation of 'figuration', denoting the process of change in which individuals and society are linked together through patterns of interaction-thus, not least, attempting to overcome analytical dichotomies between individual agency and structure.

9 I use the term 'field' here in Bourdieu's sense, i.e. as a multi-dimensional social space in which the actors are positioned according to the absolute volume and relative composition of their capital. Rather than being a static arena, every field "is the site of a more or less overt struggle over the definitions over the legitimate principles of divisions of the field" (Bourdieu 1985: 734), in which actors struggle for dominant positions within the social space as well as, interwovenly, with regard to the symbolic production of meanings, labels, distinctions, etc. From a different perspective, see also Taylor 2004 for the importance of symbolic production and the sites of such struggles in Western society. 
and the private in an illegal (or illegitimate) way. In short, corruption is a phenomenon of a functionally differentiated society. ${ }^{10}$ These boundaries, in particular the separation of public office from private property were only fully formalised and institutionalised in most Western countries in the 2oth century. In this sense (if not in a moral sense), the phenomenon and problematisation of corruption is relatively new. Hence, when the phenomenon of corruption is explored, it is always, in a mediated or immediate sense, also state/society-relationships and specific patterns of interactions that are being analysed: through the lens of corruption it is the 'modern' state, its ideologies, its representations that are ultimately being analysed.

Linked to this premise, there is a second facet that needs to be taken into consideration, namely that the study of corruption offers a highly revealing mirror into how political order is both organised and rendered intelligible by social actors: on the one hand, what structures and public institutions are seen to be legitimate and endowed with authority, on the other hand, what conceptions and images political order is derived from, what are the referents of political struggles and articulations. As Olivier de Sardan categorically states, the "process of state-apparatus building during the twentieth century, a process that is far from being achieved, is obviously fundamental not only for the production of corruption itself, but for the production of a cultural embeddedness of corruption" (Olivier de Sardan 1999: 26). An analysis of the production, structuration and culture of state(hood) then moves to centre stage-instead of understanding corruption as a practice or phenomenon signifying conflict, i.e. conflict between the formal and the informal, the public and the private, the analysis needs to follow iterated and institutionalised practices that are, socially or legally, deemed to be 'corrupt'.

In other words, what is of interest here are the incentives informing individual acts of corruption, or even the attributes of particular institutions, such as the legal framework, the judiciary, the political process, etc. that frame corrupt behaviour. The analytic point of departure in this study draws on a systemic approach to corruption: an understanding that, in Johnston's words, sees corruption “as a systemic problem having to do

10 On a practical level, this can be underlined by the recent problematisation and criminalisation of so-called 'private-to-private' corruption, i.e. practices which do not involve the public sector or a public official, but are considered problematic forms of conflict of interests or misappropriation between representatives of the private sector, civil society or the general public. For a discussion see Koechlin/Ledergerber 2004. 
with the sources, uses, limits, and accountability of wealth and power" (Johnston 2004: 22). Although Johnston treats corruption classically as "the abuse of public roles of resources for private benefit," he emphasises

that terms such as 'abuse', 'public', 'private' and even 'benefit' are matters of considerable ambiguity or dispute in many societies. [...] Rather than ending the confusion over what constitutes a corrupt act, this approach puts conflicts over standards and ambiguities about the public-private distinction at centre stage (Johnston 2004: 22-23, emphasis in original).

Drawing on this understanding of corruption, the sociological question of corruption then becomes less one of individual or social deviance ${ }^{11}$ from the prevailing social, political or legal order. Rather, in an empirically more open way the question becomes one of social struggles about norms, power and access to (material and symbolic) resources. ${ }^{12}$

Bringing these introductory remarks to an end, this approach draws a full circle to some of the first influential studies on corruption, which conceptualised corruption in terms of political development, political order and social change. Corruption in the heyday of modernisation theory was inevitably linked to or emerged from reflections on the conditions of development. So what I propose to undertake in the following sections is to first, describe the discourse on corruption in terms of modernisation and development, using selected authors to illustrate how corruption was conceptualised with regard to the problem of political stability, economic

11 Surprisingly, there has been very little analysis of corruption as deviance in a sociological sense, although 'deviance' is routinely implied when the distance between legal and moral orders is invoked, or the conflicts between different rationalities that corrupt practices denote are stressed. A closer look at Emile Durkheim's classic conceptualisation shows that 'deviance' in his sense would actually provide a more multifaceted analytical entry-point than merely pointing to the disintegrative and dysfunctional aspects. Indeed, deviance, with Durkheim, can be conceptualised as being 'functional' for society: although in his view modern societies are characterised by rising levels of anomie (i.e. threats of social disintegration and unravelling of a common moral order), resulting deviance can also serve to make visible the boundaries of this order. Ensuing public 'labelling' of deviant behaviour can serve as a space of negotiation and, (functionally) at best, forge unity on what is considered to be right and wrong. In other words, deviance conceptualised in this way does not exclude its assimilative or integrative function, on the contrary (see Durkheim 1990, 2002). These comments aside, here corruption will not be explored in more detail through the lens of deviance; however, further down the (dis)integrative characteristics of corruption will be explored more fully.

12 This approach is far closer to an understanding of state and statehood as understood, for instance, by Migdal, who undercuts metaphors of 'strong' or 'weak' states by putting the struggles between different (state as well as non-state) actors on centre stage, especially with regard to the authority and legitimacy of rules about the public affairs and the boundaries of private life (Migdal 2001: 62-71). 
growth and social transformation in new states (Section 2). Outlining the positions of three influential theorists of that era, namely Samuel Huntington, James Scott and Gunnar Myrdal, as a frame of reference that is still seminal for contemporary theory on corruption, paves the way for an overview over the assumptions regarding the structural and cultural configurations of 'corrupt' societies. As will be demonstrated, these early thoughts on corruption are still highly insightful; one could even go as far as to say that, with the exception of some radicalised theories on state and statehood, large parts of contemporary literature on corruption and development still draw from or even fall behind these early scholars. Second, I have distinguished three groups of theories on corruption in developing countries that have evolved since then. ${ }^{13}$ This classification is not intended as a rigorous taxonomy, rather as a sketch rendering the patterning of certain statements and discursive formations of corruption in Africa visible. They have been distinguished according to their emphasis on rules and regimes (Section 3), values and practices (Section 4), and political order (Section 5) respectively. Against this backdrop of concepts and articulations on corruption, lastly, an attempt to conceptualise a preliminary sociology of corruption will be made (Section 6), theoretically framing corruption in terms of inclusion, exclusion, and political struggles.

\section{Corruption and Political Development: Assimilation and Integration}

The rapid social change witnessed in the post-World War II period in Asia, Africa and Latin America produced pervasive corruption in most developing countries. Discussing this phenomena in an influential paper named "What is the Problem about Corruption" in 1965, a prominent scholar of the period remarked: "It is clear that new states are very likely to be the scene of a great deal of behaviour that will be called corrupt" (Leys 1965: 224) - implying in his wording already a key problematique, namely the the definition of and legal-normative framework regulating 'corruption'. At the same time, given the challenges facing the newly independent countries, the conditions and types of economic, social and political development were on centre stage. For scholars of the era, hence, the framing question was not only to explain whence such a proliferation of corruption, but

13 In the first volume of the excellent compilation of seminal articles, "Explaining Corruption" by Williams (ed.) 2000, the analytic trajectory and loops in corruption theories over the past 30 years can easily be traced. 
also whether and how corruption is good or bad for development. Against the backdrop of rapid social, political and economic changes in developing countries, the objectives of economic growth and social differentiation were on the top of the modernisation agenda. In this context, corruption was conceived to be either a phenomenon indicating the palpable friction between 'modern/market' and 'traditional/parochial' principles and values, or else a mechanism of reducing and mediating this friction. ${ }^{14}$ The new formal political and economic systems were under huge pressure to meet social demands at the same time as being at odds with local realities. Given the tensions created by modernisation, conceivably corruption can both facilitate socio-economic transformation and political integration as well as undermine political stability and economic progress, depending on the analytical angle chosen. In other words, corruption can be shown to be functional in the short to medium run; however, in the long run the divergence between the disregarded formal principles and relevant political practices seems to lead to social, political and economic disjunction and alienation. Again, this must not necessarily lead to disintegration and collapse, as the history of European countries, the USA, or the more recent past of developing countries have shown. ${ }^{15}$

The most prominent exponent of this line of thought is Samuel Huntington, who carved a conceptual benchmark in his widely acclaimed book on political development (Huntington 1969 [1968]) by examining the function of corruption in phases of strained and decayed political order. ${ }^{16}$ He correlates the absence of political institutionalisation with the level of corruption, both of which are symptomatic for modernising countries. The causes of this general correlation have both cultural as well as structural roots. Pre-empting Huntington's conclusion, he depicts corruption as an integrative mechanism mediating between the antagonistic forces produced and aggravated by modernisation. Huntington argues elaborately on the basis of his enquiry into the causes of corruption, and his insights still provide the basis for current analyses of transforming societies and roots of political patronage.

14 Seminally, Scott carved a benchmark by distinguishing 'market corruption', based on economic market exchange, and 'parochial corruption', based on social exchange (Scott 1969a), a distinction which shall be discussed further down.

15 For a detailed discussion of corruption in European states see seminally van Klaveren (1957); for an analysis of the 'machine politics' of early 2oth century USA, see Scott 1969b; for a typology of corruption and political systems see Johnston 2005 .

16 For a detailed critique of Huntington's conceptualisation of corruption see Alatas 2000 . 
Firstly, he observes that the introduction of new political standards lead to established patterns of behaviour becoming disrupted, disregarded or even illegal. The conflict between 'modern' and 'traditional' standards creates uncertainty with regard to the 'right' behaviour. As Huntington points out, the "calling into question of old standards, moreover, tends to undermine the legitimacy of all standards" (Huntington 1969: 6o), thus opening an undefined space in which individuals and groups can act in ways justified by (n)either 'old' (n)or 'new' norms. ${ }^{17}$ Secondly, the distinction between public interest and private role is seminal for the whole concept of political and social obligation and responsibility. Modernisation produces such a distinction, but evidently not in an idealtypical way. On the one hand, corruption only becomes conceivable as a function of the (specifically modern) differentiation between the private and the public sphere. On the other hand, the pressures that the unyielding logic of impartiality, rationalisation and achievement standards exercise on individuals and communities may themselves stimulate greater need for the protection of family ties and other affective or ascriptive bonds of solidarity. ${ }^{18}$ Thirdly, there is a strong socio-political incentive for corruption, which acts as a redistributive mechanism between political power and economic wealth. It is worth citing Huntington at length, for here he offers an original insight:

Modernization also contributes to corruption by creating new sources of wealth and power, the relation of which to politics is as yet undefined by the traditional norms of the society and on which the modern norms are not yet accepted by the dominant groups within society. Corruption in this sense is a direct product of the rise of new groups with new resources and the efforts of these groups to make themselves effective within the political sphere. Corruption may be the means of assimilating new groups into the political system by irregular means because the system has been unable to adapt sufficiently fast to provide legitimate and acceptable means for this purpose (Huntington 1969: 61; emphasis added).

17 The recent transformations of formerly socialist, centrally planned societies underscore this point. For an early discussion of the effects of liberalisation on corruptionprecisely within this sphere of insecurity and regulatory void-see Harriss-White 1996, or for a more in-depth contribution see Cartier-Bresson 2000.

18 This is an interesting take on Weber's 'iron cage' of rationalisation. Whereas for Weber $(1985,2004)$ the relentless expansion of bureaucratic-legal domination into all spheres of life leads to a shrinking, a disappearance of other value and norm systems, Huntington re-interprets the expansion by observing a higher premium accorded to such non-rational value and exchange systems; instead of disappearing, they become more valuable to social actors. 
In other words, the (new) possibility to trade money for political power and social prestige, and vice-versa, works as an arbitrating and adjustment mechanism balancing different levels of enfranchisement within a rapidly changing society by assimilating (economically, politically, socially) disjoined groups. ${ }^{19}$ The consequences of this arbitration, however, depend on the trajectory of political relations ${ }^{20}$ — on the potential for emancipation and rationalisation, as he expounds.

Fourthly, under the condition of economic underdevelopment and surging socio-political demands, modernisation of states is characterised by "the expansion of governmental authority and the multiplication of the activities subjected to governmental regulation" (Huntington 1969: 61). The extent of interaction between citizens and the public sector is multiplied accordingly, and proportionally the opportunity for corruption. ${ }^{21}$ Coupling the expansion of state activities with the uneven institutionalisation of formal roles and norms, a situation is created in which corruption becomes the prevalent behaviour of public officials. ${ }^{22}$

19 For a more recent pioneering contribution on such exchange mechanisms see Reno's analysis of shadow states and warlord politics (Reno 1995, 1997).

20 In a recent study on the effect of liberalisation programs on Mozambique, Harrison uses an apt term to capture these fluid processes indicated by defining corruption as 'boundary politics', in which social actors attempt to "stabilise and/or valorise permeable social boundaries" (Harrison 1999: 538). Rather than conceptualising corruption as the instrumentalisation of politics, Harrison views corruption as the signifier of shifting boundaries, manifested in concrete practices on the boundaries between the national and the international economy, in contended societal relationships, and subsequently thriving in those open spaces "along the social boundaries dynamised by liberalisation" (Harrison 1999: 549).

21 Huntington also puts into this context the extreme efforts to 'be modern' that can be witnessed in some developing countries - to be more Prussian than the Prussians, so to speak: "The ideals of honesty, probity, universalism, and merit often become so overriding that individuals and groups come to condemn as corrupt in their own society practices which are accepted as normal and even legitimate in more modern societies. [...] The escalation of standards in a modernizing society and the concomitant devaluation and rejection of politics represent the victory of the values of modernity over the needs of society" (Huntington 1969: 62-63).

22 In an early and important contribution to the discussion, Leff highlights the positive effects of corruption on economic development, based on the (now mainstream) assumption that the public sector does not operate perfectly. Challenging the (then mainstream) assumption that strong etatist policies are prerequisite for concerted developmental efforts, Leff underlines the risk of wrong policies based on uninformed or self-interested criteria. He states that in "many underdeveloped countries, the bureaucracy may be the lagging rather than the leading sector" (Leff 1964: 13). In this situation corruption acts as a safeguard against bad policies as well as a lubricant for economic development and entrepreneurial innovation. 
Huntington widens his analysis by comparing the function and the causes of violence and corruption in modernising societies.

Both are encouraged by modernization; both are symptomatic of the weakness of political institutions; both are characteristic of what we shall subsequently call praetorian societies; both are means by which individuals and groups link themselves to the political society and, indeed, participate in the system in ways which violate the mores of the system. Hence the society which has a high capacity for corruption also has a high capacity for violence. [...] The prevalence of violence, however, does pose a greater threat to the functioning of the system than the prevalence of corruption. In the absence of agreement on public purposes, corruption substitutes agreement on private goals, while violence substitutes conflict over public or private ends. [...] Violence [...] is a symptom of more extreme alienation (Huntington 1969: 63-64).

Huntington shows great perception in exposing the political implications of violence and corruption as well as the nature of their relationship with political order. ${ }^{23}$ Although he is often critiqued for his functionalist approach to corruption, ${ }^{24}$ highlighting the integrative and assimilative functions and glossing over its destabilising and disintegrative potential, the quote shows that he is more than aware of such dysfunctionalities, that he terms 'alienation' from public interests. However, analysing corruption in terms of specific practices of a systemic nature that link certain social groups to the political society, he places emphasis on the dynamics of social change in which corruption acts as a transformative mechanism; but a mechanism that only potentially, not necessarily leads to integration and assimilation.

Huntington concludes that although corruption by definition runs against the ideal of modernisation, it is endowed with a specific function within the adapting social structure: it provides a creative and responsive medium to the diverse and at times incompatible norms and social

${ }^{23}$ The nexus between violence and corruption is one that has become more and more prevalent in African countries, and it seems that the nature of their relationship as well as the implications for political order are far from clarified. The recognition of such 'extreme forms of alienation' demarcated by the prevalence of violence anticipates current phenomena of African societies. In the wake of the protracted conflicts and social emergencies scarring many African countries since the nineties, violence seems to have become the hallmark of African politics. See, for instance, Mbembe 2002 who employs the term 'necropower' to conceptualise the brute force of African elites. For excellent analyses and casestudies of violent conflicts in Africa see Lemarchand 2009; the case-studies in Kaarlsholm (ed.) 2006; or the contributions in Chabal/Engel/Gentili 2005. For a general outline of a sociology of violence see pioneeringly von Trotha 1997.

24 For a trenchant critique see for instance Alatas 1990. 
practices within a modern political system. He clearly observes that corruption can and does weaken political development by undermining the government bureaucracy and public interests, but remarks at the same time that corrupt practices may in fact stabilise political order in the short - to medium term. ${ }^{25} \mathrm{He}$ goes on to state that in the long-term, the organisation and structuring of political participation in the form of political parties is "the principal institution of modern politics" (Huntington 1969: 71); but far from necessarily impeding the evolution of modern politics, Huntington asserts that corruption may be the facilitator of a fledgling political integration and organisation, which gradually transcend the particularistic interests they evolved from in a virtuous spiral of increasing autonomy and authority. ${ }^{26}$

This view provides a frame of reference to another prominent scholar, namely James Scott, who in his "Analysis of Corruption in Developing Nations" of 1969 makes one of the most interesting empirical analyses of corruption of that era. As a point of departure he dissects the discrepancy between social norms and legal norms observable particularly in developing countries. Unlike Western societies upon which they are modelled, the legal framework in most developing countries has been adopted in an ahistorical fashion, rather than being a product of political struggles between social groups and classes. ${ }^{27}$ This creates a situation in which "[m] ost developing nations have not only taken over Western legal forms; they have often adopted the most restrictive and demanding forms available" (Scott 1969a: 319). This rings true for developing nations a mere or so decade old, as they were at the time. More saliently, it is still of acute relevance today: most legal reforms are produced by the development

25 In contrast to contemporary scholars such as Chabal 1999, 2009, who conceptualise the function of corruption in terms of instrumentalising and stabilising a permanent state of disorder, the function of corruption in Huntington's analysis is the opposite: namely to mediate between potentially conflicting norms, values and practices, to act as a kind of buffering zone of social, economic and political tensions arising through rapid social change.

26 In his enquiry dating from the same period, Scott observes that one possible trajectory would be the transition from a bureaucratic political system to a political party system, where legitimate ways of influencing governments are created; e.g. the transition from an illegal bribe to a politician to a legal contribution to a political campaign. The point from the perspective of political development is not that the overall level of corruption necessarily is lowered, but that the transition from illegitimate and illegal to legitimate and legal is achieved, thus institutionalising non-corrupt practices which would have been deemed corrupt in a more bureaucratic system (Scott 1969a: 74).

27 For seminal theories on political contention and struggles and political orders see Tilly 1990, 2004 and Tilly/Tarrow 2007. 
apparatus, financed by donors and written by external consultants for recipient governments - a problem that is illustrated by the highly sophisticated constitutions and legal framework of recently democratised African countries, incorporating the highest standards of human rights and accountability institutions. ${ }^{28}$ This tightening and simultaneous heightening of the legal framework leads to an almost automatic expansion of corruption, albeit primarily in nominal terms: whilst there may be continuity in prevailing social practices and values, the (legal) framework has shifted and lead to the legal stigmatisation of such practices, now deemed to be 'corrupt' in legal if not necessarily in social judgement. ${ }^{29}$

Scott's key interest, however, is not primarily the distance between legal and social norms, although this remains a key characteristic and prime frame of reference in contemporary studies of corruption. Scott's most innovative analytical contribution is the differentiated conceptualisation of corruption as an a priori neutral form of political influence. The question is not legality or illegality, or even legitimacy or illegitimacy. The pivotal question is access to political decision-making: Scott treats corruption as an alternative means of interest articulation. In his words, "this approach highlights the functional equivalence of a variety of acts of political influence, some of which violate all standards of community ethics and some of which are totally beyond reproach" (Scott 1969a: 322). ${ }^{30}$ Like Huntington, he too is interested in the nexus between wealth and power, more explicitly looking at corruption as a means for social groups to access the political system. When does wealth act as a political resource, in which ways, by which groups? He concludes that it depends largely on the nature of the political system. It is in this analytical context that he makes his widely quoted ideal-typical distinction between 'parochial' corruption and 'market' corruption: the former denoting a situation where only ties of kinship, caste, etc. determine access to the

28 For a discussion on problems and opportunities of the glaring discrepancy between the formal legal framework and socio-political and socio-economic realities with regard to corruption and human rights in Malawi see Koechlin/Sepulveda 2009.

29 Although Scott's analysis allows some significant inference on the definitional power of certain actors and the frictions with the socio-cultural matrix of society, the emergence of attitudes and value structures that support the stigmatisation of (legally) corrupt practices is not discussed in his contribution.

30 Scott's definition echoes an earlier, much noted contribution by the economist Nathanial Leff, who defines corruption crisply as "an extralegal institution used by individuals or groups to gain influence over the actions of the bureaucracy. As such the existence of corruption per se only indicates that that these groups participate in the decision making process to a greater extent than they would otherwise" (Leff 1964: 8). 
Table 1: Corruption and Access to the Political System

\begin{tabular}{|c|c|c|c|}
\hline \multirow{2}{*}{$\begin{array}{l}\text { Generally easy } \\
\text { access to formal } \\
\text { political system }\end{array}$} & \multicolumn{3}{|c|}{$\begin{array}{l}\text { Groups often securing access primarily by means of corrup- } \\
\text { tion because denied formal access by virtue of: }\end{array}$} \\
\hline & Ideological Reasons & Parochial Reasons & Lack of Organization \\
\hline 1. Political elite & $\begin{array}{l}\text { 1. Indigenous } \\
\text { commercial and } \\
\text { industrial groups }\end{array}$ & $\begin{array}{l}\text { 1. Minority } \\
\text { ethnic or } \\
\text { religious groups }\end{array}$ & $\begin{array}{l}\text { 1. Unorganized } \\
\text { peasants }\end{array}$ \\
\hline $\begin{array}{l}\text { 2. Cadre, branches } \\
\text { of ruling party }\end{array}$ & $\begin{array}{l}\text { 2. Foreign business } \\
\text { interests }\end{array}$ & & $\begin{array}{l}\text { 2. Unorganized } \\
\text { urban lower class }\end{array}$ \\
\hline $\begin{array}{l}\text { 3. Civil servants } \\
\text { associations } \\
\text { 4. Professional } \\
\text { associations }\end{array}$ & $\begin{array}{l}\text { 3. Political } \\
\text { opposition }\end{array}$ & & \\
\hline 5. Trade unions & & & \\
\hline
\end{tabular}

(Source: Scott 1969a: 329)

favours of power-holders, while the latter signifies an impersonal process in which influence is accorded to those who can pay most, regardless of their person. ${ }^{31}$

Here, the type of political order is on centre stage; more precisely, the type of political order framing mechanisms of inclusion and exclusion. ${ }^{32}$ Where formal possibilities of 'voice' 33 by certain social groups are restricted, corruption poses an informal way to access the political system. What is striking in this table is the importance that Scott accords to organised interests, or rather to the type and level of organisation of interests of particular interests. This is a point I will be taking up in some detail in

31 The definitions are taken nearly verbatim from Scott, but without the footnotes in original (Scott 1969a: 330); see also Table 1 'Access to Political System' (Scott 1969a: 329).

32 Scott explicitly focuses on types of corruption and access to specific types of political systems, or more precisely, on the relationship between type of corruption and type of political system. This is distinct from a broader conceptualisation framing corruption within the institutional placement and organisational characteristics of (informal or 'extra-legal') networks. For seminal contributions studies on clientelism see Eisenstadt/ Rominger 1984; Eisenstadt/Lemarchand 1981, or the contributions in Gellner/Waterbury (eds.) (1975).

33 See Hirschman 1970 for his seminal analysis of exit, voice and loyalty as key political and economic actions and their relationship with political (or organisational) responsiveness. 
the case-studies of the following chapters, where professional associations and corruption in Tanzania will be explored more fully.

Scott carves out two further issues: first, social reality always produces messy and fuzzy connections between parochial and market corruption, or rather: between parochial and market processes of articulation and integration. ${ }^{34}$ Second, the question of the impact of corruption on political stability depends on the relationship of the predominant forms of corruption with prevailing social structures. Scott's premise is that the closer the 'fit' is between corruption and existing social structures, the less politically disruptive such corruption is (e.g. ethnic-based corruption is less disruptive in a ethnically organised society than in a class-based society). The hypothesis is plausible in that 'fits' between social structures and 'corrupt' practices narrow down the fields of social struggles and potentially increase the potential of connecting actors and discourses. However, with the benefit of hindsight, this assumption that certain social structures fit neatly and functionally with corruption has been rendered downright cynical. In the intermittent forty years, a plethora of fundamentally disrupting and destructive conflicts in Africa have been a product of precisely this close 'fit' between social structures and corrupt practices. Instead of leading to a stable integration in the political system, such a 'fit' has lead to violent politics of exclusion and particularism. ${ }^{35}$

One of the first scholars to be at odds with this functional view of corruption is Myrdal (1968). He carves out the destabilising force of corrupt practices, especially in countries undergoing fundamental socio-economic transformations. In his renowned study on South Asia, published in the same year as Huntington's book, he states that "it is obvious that the extent of corruption has a direct bearing on the stability of South Asian governments" (Myrdal 1968: 938; emphasis in original). His initial observation is that in developing countries in general, 'corruption' has become a political resource: governments lose elections over allegations of corruption,

34 This approach has since been elaborated and substantiated by Michael Johnston in his book on "Syndromes of Corruption" (Johnston 2005), where he frames types of corruption in relation to different types of political systems.

35 A recent example is the violence that shook Kenya in the aftermath of the elections of 2007 , due to precisely such close 'fits' between political order and ethnic structure, leading to vertical boundaries of exclusion along ethnic lines. The turbulent and often violent political history of highly corrupt Nigeria would be another case in point. For highly interesting contributions on the interrelationship between ethnicity, patronage and politics in African states that explores the issues that Scott touches upon in more analytical depth see Berman et al. 2004. 
political parties win seats on an anti-corruption ticket, and, more seriously, regimes are toppled and coups are justified with the promise of eradicating corruption. ${ }^{36}$ Although Myrdal chooses a different approach to Huntington by using the 'folklore', i.e. popular perception of corruption, as an analytical point of departure, he comes to similar conclusions with regard to the causes of corruption in developing countries. However, he places more emphasis on the nexus between cultural factors and economic necessities. In particular, the 'plural societies' of South Asian countries are characterised by the "fragmentation of loyalties and, in particular, little loyalty to the community as a whole, whether on the local or the national level" (Myrdal 1968: 949). Hence, they are historically predisposed to express more loyalty to less inclusive communities (such as family, caste, or ethnic and religious groups). Modernisation and the concomitant emancipation from such ascriptive loyalties and dependencies have the potential to fundamentally revolutionise static social structures. However, setting these social practices into the context of a fraught economy, i.e. inexistent, imperfect or fragmented market of goods and services, the socio-economic environment is such that the ensuing economic behaviour cannot be solely guided by 'emancipatory' calculations. ${ }^{37}$ As Myrdal elaborates,

36 At that time, the fight against corruption was not part of the international development discourse, but was primarily a domestic issue, highlighting the struggles over political production and symbolic production (in Bourdieu's sense). However, corruption as a powerful political resource has become even more salient since the rise of the governance and anti-corruption discourse - this is particularly evident in the African context, where the 'third wave of democratisation' (Huntington 1991), i.e. the introduction of multi-party politics in the early nineties, made (the fight against) corruption a crucial argument for incumbents and the opposition alike. It is probably not an exaggeration to say that there has been no election in Africa since the end of the Cold War in which allegations over corruption and concrete corruption scandals have not played a central role. For one example see the case-studies of 2003 and 2010 on Tanzania in this volume (Chapters 3 and 4, below); for further examples consider the allegations over corruption of the electoral commission in Kenya and its violent aftermath in December 2007, or the public debates and political unrest in South Africa over the corruption allegations of the now president Jacob Zuma, to name but some of the internationally most visible. More generally, see Schatzberg (2001: 24-27) for the connection between the moral matrix of political legitimacy and its conditions in the late eighties and nineties under which such legitimacy is seen to give way to political corruption, couched in the terms of greed and overconsumption.

37 The lack of emancipation, i.e. the absence of liberation from material, political and social dependencies in spite of fundamental structural transformations is a central concern of most contemporary Africanists (see Mamdani 1996; Mbembe 2002). Focusing on the enduring reality of subjecthood (as opposed to citizenship) analysed so astutely by Mamdani, Chabal terms the historically framed closing of political spaces a 'bastard form of political rule': "Far from bestowing on Africans political emancipation, colonial 
'connections' must fill the gap. These 'connections' range all the way from the absolute dependence of attached labor in agriculture and the peasants' relations with moneylenders and landlords, which are determined by custom and power, to the special considerations that lead to nepotism even in big business. In such a setting a bribe to a person holding a public position is not clearly differentiated from the 'gifts', tributes, and other burdens sanctioned in traditional, pre-capitalist society or the special obligations attached to a favor given at any social level (Myrdal 1968: 948).

This description illustrates a key feature of corruption, operating not within dominant legal-rational boundaries, but in permeable arenas framed by diverse exchange rationalities and varying degrees and types of coercion. ${ }^{38}$

In other words, existing social structures and cultural codes that permeate all spheres of society - 'traditional' and 'modern'; economic, social and political-make inclusion of citizens into the economic and political system a function of particular connections. The stability of such a social order, defined and glued together by particularistic loyalties, then becomes a function of the resources and power of one particular social group. This order explains the high incidence of 'corruption' or, better: boundary-crossing connections, as well as the widespread politicisation of corruption. Corruption is the means to access political and economic resources, and is accorded a high premium, especially by those who are not part of the right network, those who are excluded. Of all the authors, Myrdal emphasises the dark sides of such exclusionary socio-political relations most strongly, ranging from issues of dependence, marginalisation and social polarisation, to the negative impact of corruption in terms of loss of legitimacy and waste of resources. In Myrdal's view, the prevalence of corruption is a mine-field for society, for it fosters political instability as well as more latent processes subverting the ideals of modernisation ${ }^{39}$ -

rulers thus instituted a dual form of subjecthood, which undermined their modernising discourse and created a bastard form of political rule" (Chabal 2009: 90). The question of emancipation is one I shall return to in the next chapter (Chapter 2, below).

38 See also Cartier-Bresson 1997 on different exchange relationships of corruption and their implications.

39 For the latter condition, observable in many developing countries, Myrdal (see Myrdal 1968: 950) coined the expression "soft state", a state in which 'social discipline' [sic] is lacking, public institutions are malleable and neither officials nor politicians adhere to their duties. This notion of a 'cultural' dimension of development, not in the sense of predetermined norms and customs, but in the meta-political sense of value-based consensus on the essence of socio-political order echoes Schumpeter's insight of the normative preconditions of functioning liberal democratic orders (see Schumpeter 1993). 
an analysis that pre-empts the gist of many contemporary theories on African politics, as will be discussed further down.

The key characteristics of corruption and development of this early discourse are portrayed in distinct but interrelated ways. Firstly, all three authors carefully trace the relationship between social, political and economic order and the function that corruption takes on in terms of inclusion and assimilation into such spheres. Although they highlight different aspects, stressing political access, political integration or political destabilisation, respectively, they provide a multidimensional understanding of corruption in relationship echo Scott's empirical postulate that "it is impossible to ascertain the effects of corruption on political integration, income distribution, or economic growth without first asking who benefits in what ways from what kinds of corruption" (Scott 1969a: 340).

Secondly, they carve out that power, accumulation and the exercise of violence are not regulated primarily by the rule of law; the rule of law merely features as one amongst alternative systems of social reference. The 'state', i.e. public institutions function in practice along different lines. One common feature of these early and seminal studies on political change is their emphasis on the prime importance of the political office in developing states. The political office is the clearing-house for status and prestige as well as for economic and political resources. Therefore, access to and control of the political centre is synonymous with access to and control of the distribution of benefits, which is key to cementing political support. The state neither has the primacy over nor capability to implement the rules of public affairs nor what Bourdieu terms (in a neat twist of Weber's much quoted definition of the state) the monopoly of legitimate symbolic violence (Bourdieu 1985: 732), i.e. the authority to define and impose 'official' viewpoints. Insofar the state is weakly institutionalised, the importance of 'reciprocity' 40 becomes paramount as a means of securing and defining predictability. The uneven internalisation of formal norms and political processes, and uncertainty about the sources of legitimacy and capacity of the political system, leads to a situation in which political power is exchanged with status and material wealth, so that short-run, concrete inducements serve to secure political cooperation

40 In this early discussion, the notion of reciprocity was utilised in the simple sense of exchange obligations. Only later did Scott anchor a specific understanding of reciprocity to the concept of the 'moral economy' in rural, underdeveloped states (Scott 1976); and Hyden in particular highlighted reciprocity as a focal point of African social relations and the essence of the 'economy of affection' (Hyden 1980; 1995). 
and support. The underlying assumption shines through (maybe with the exception of Myrdal) that societies will move on from this phase to the next, rational-legal phase depending on the "process of industrialisation as new economic arrangements take hold and provide new focuses of identification and loyalty" (Scott 1969a: 279). ${ }^{41}$ They all sharing similar premises with regard to necessary processes of value-formation and social differentiation. Still, the analysed dynamics and features of the political order in developing societies depicts political institutions that are intimately-but unevenly and informally-embedded in society, economic opportunities that are framed by political offices, and social practices evolving and crystallising within parochial as well as market norm systems.

\section{The Political Economy of Corruption: Rules and Regimes}

Evidently, in this early and defining discussion on corruption there seems to be a level of consensus on the causes of corruption in developing countries, but no general conclusions about its effects. The only generally valid assumption regards the long-term effects on political development; although many early scholars of corruption ${ }^{42}$ argued that corruption can conceivably be functional in the short-to medium run, all studies conclude that in the long-run corruption undermines the objectives of 'modernisation' if it does not evolve beyond its prebendal roots. As the preceding section illustrated, the line between 'functional' and 'dysfunctional' corruption is not only blurred, but also bound up in a complex configuration. A variety of dynamic elements significantly shape the context of corruption, ranging from the conditions of economic development to the values and conventions framing social practices.

However, in the decade following these seminal conceptualisations of corruption, the interest in corruption as such waned. With few exceptions, ${ }^{43}$

41 However, as the study by Scott on Machine Politics in the USA shows, this transition is historically contingent, and therefore by no means linear or even predictable (Scott 196gb).

42 Apart from the arguments made by Huntington (1969) or Scott (1969a) discussed, see in particular Leff 1964, Nye 1967, or Banfield 1975 .

43 Such as the key article by Banfield, where he develops the concept of principal-agent relations (Banfield 1975); Rose-Ackermann's seminal study on the political economy of corruption (Rose-Ackermann 1978); or the pioneering volume on political corruption in historical and comparative analysis, originally edited by Arnold Heidenheimer and Victor LeVine in 1970, and subsequently reprinted in many co-editions with eminent authors such as Michael Johnston (for the latest edition see Heidenheimer et al. 2009). 
corruption came to be understood as an intrinsic structural feature of many Third World states. Reviewing the literature of the seventies, the 'problem about corruption',44 if it was addressed at all, mutated into the question of regime types in the Third World, where corruption was one significant but not explicitly analysed determinant. The analysis of 'corruption' moved out of academic fashion, only to be replaced by an interest in patronage and clientelism as key features of Third World political systems.

Most importantly, the political science of development evolving during this time produced the distinction between two models of political regimes of the Third World: the corporatist state of Latin America ${ }^{45}$ and the neo-patrimonial state of Sub-Saharan Africa. ${ }^{46}$ Analogous to Huntington's notion of the praetorian character of political competition, where neither rules nor political institutions are firmly anchored in society, both concepts attempt to explain the modes of containing political disorder and social confrontation in terms of personal relations and the specific relationship with the formal structure of the state. On centre-stage are the mechanisms of allocation, distribution and redistribution of economic and political resources. Although both concepts revolve around patronage and clientelism as structuring mechanisms of political order, the main difference between them lies in the degree of legal-rational institutionalisation of bureaucratic structures. ${ }^{47}$

Until this day, the notion of the neo-patrimonial state plays a dominant, if increasingly contested role in explaining 'politics' and 'development' in Africa. ${ }^{48}$ Its key role in explaining personalistic and corrupt politics and their effects on the continent neo-patrimonialism shall serve as an entrypoint into a more pointed probe into African politics. A neo-patrimonial state is conventionally understood to be a state which formally adheres to legal-rational standards, but operates within a double frame of reference,

44 "What is the Problem about Corruption" is the title of a seminal article on corruption and development, written by Colin Leys in 1965 (see Leys 1965).

45 For early literature on corporatism in Latin America see the influential volume on authoritarianism and corporatism in Latin America by Malloy (ed.) 1977, including a contribution by O'Donnell on what he calls "Corporatism and the Question of the State" (O’Donnell 1977).

46 For early literature on neo-patrimonialism in Sub-Saharan Africa see, for instance, Lemarchand/Legg 1972.

47 For critical contributions questioning the distinction between the two concepts see classically Hammergren 1977; for a more recent discussion in the light of the resurged interest in clientelism and neo-patrimonialism see Theobald 1999.

48 With regard to development policy, see, for instance, World Bank 1989 or 1997. 
namely a private/social as well as public/official one, and thus pervades the public/private boundary the modern state is based on. Of course, as already Max Weber made clear, no political system operates to the exclusion of all other forms of 'rationality', but idealtypically there is a dominant form of rationality which marginalises other existing principles of political relations. ${ }^{49}$ Patrimonial administrations are characterised by the legitimate private appropriation of the spoils of office, such as taxes, customs, land, labour, etc. as part of the routine exercise of political office. ${ }^{50}$ Hence, the prefix 'neo' refers to a political order that is formally based on the legal-abstract rationality of public administration-and therefore a 'modern' state-but in practice adheres to a patrimonial rationality (or more precisely: patrimonial realities). Engel/Erdmann sum up its characteristics in the following words:

Neopatrimonialism is a mix of two types of political domination. It is a conjunction of patrimonial and legal-rational bureaucratic domination. The exercise of power in neo-patrimonial regimes is erratic [...]. Finally, neopatrimonialism corresponds with authoritarian politics and rent-seeking culture, whereas legal-rational domination relates to democracy and a market economy (Erdmann/Engel 2006: 31).

Evidently, a more grounded understanding of the terms patronage and clientelism is called for. As Gellner/Waterbury highlight: "What makes a patronage society is not the sheer presence of this syndrome, but its prominent or dominant position, to the detriment of other principles of social organisation" (Gellner/Waterbury 1975: 4) ${ }^{51}$ Important here is that patrimonial or patronage societies are not bound to a specific historical period; on the contrary, a variety of concrete forms exist in contemporary societies. ${ }^{52}$ Perhaps one of the most interesting conceptualisations of such relations stems from the work of Eisenstadt and his fellow authors $(1978,1984)$. Here, patron-client relations are framed in terms of specific

49 For a recent theoretical innovation highlighting the material and symbolic struggles of and between states as well as non-state actors within societies organised along formallegal lines see Migdal 2001.

50 See Weber 1985; also Breuer 1998 on a typology of states in their historical context.

51 Seminally on patronage, principles of social organisation and also the importance of trust see Eisenstadt/Roninger 1984.

52 For one of the most noted studies see Putnam and his fellow authors (1993), who made a seminal contribution to the concept of 'social capital' with a comparative analysis of wealthy, prosperous and dynamic Northern Italy, and poor and socio-economically static Southern Italy - the former, he concludes, being structured along weak, horizontal ties, the latter structured along hierarchical, vertical (patron-clientelistic) lines. 
modes of generalised exchanges of trust; or more particularly, on relations between (and types of) distribution of power, the flow of resources and the structure of social relations in society, with a specific analytical interest in "the different levels of continuity, or discontinuity, in the construction of the institutional order" (Eisenstadt/Roninger 1984: 28). ${ }^{53}$ In this reading, patron-client relations "indicate that the tempo and direction of change in some crucial aspects of social division of labour-as manifest above all in levels of technological and economic development-may differ from those that develop in the construction of trust and meaning, and in the regulation of power" (Eisenstadt/Roninger 1984: 28). Their key interest is hence of a more fundamental sociological nature, namely the ways that that such interpersonal relations structure trust, provide meaning and regulate power within a society, i.e. the ways in which generalised exchange mechanisms relate to specific exchange mechanisms in a society. ${ }^{54}$

According to Eisenstadt/Roninger (1984: 48-49), ${ }^{55}$ patron-client relationships are endowed with some specific characteristics that distinguish them from other relations of dependence: a) they tend to be primarily particularistic and diffuse, as opposed to universalistic and formalised; b) they are characterised by the simultaneous exchange of different resources, such as identified, for instance, in the work of Huntington or Myrdal, i.e. the exchange of instrumental, economic, political resources (on the side of patrons) with reciprocity, loyalty and solidarity (on the side of clients, although evidently, for instance, 'loyalty' can and often is articulated as a political resource); c) the latter is often tied to unconditional, interpersonal obligation; d) these relations are based on informal (albeit strongly binding) understandings, i.e. not fully legal or contractual, and often in outright opposition to the official laws of the country; e) they are organised in a vertical rather than horizontal way; and f), lastly,

patron-client relations are based on a very strong element of inequality and of differences in power between patrons and clients. [...] the most crucial element of this inequality is the monopolisation, by the patrons, of certain

53 This is of course also an intended theoretical prod against the inherent bias of 'static' societies of the structural-functionalist school, which is critiqued as "negating the creative autonomy of groups or individuals in the very construction of such order" (Eisenstadt/ Roninger 1984: 24).

54 For a detailed discussion of distinct types of patron-client systems exploring differing perceptions of corruption see also Heidenheimer 1970: 18-28.

55 See also Heidenheimer 1970 and Gellner/Waterbury 1975. 
positions which are of crucial importance for the clients-above all [...] of the access to the means of production, major markets and centres of society (Eisenstadt/Roninger 1984: 49).

This latter point is the hinge that such relations swing on: in spite of patron-client-relationships being reciprocal in character, the patrons are the gatekeepers to essential resources.

Applying these findings to social reality, an important insight is that patron-client relations are not necessarily predominantly found in developing countries; in most if not all contemporary societies such relationships exist in many differing concrete forms. Eisenstadt/Roninger (1984: 49) distinguish between the place that such relations are accorded within the broader institutional contexts of their societies - whether they constitute a) a basic aspect of the institutional matrix; b) not a basic aspect but a recognised dimension; or whether they are, c), an 'addendum' to the central institutional structure. ${ }^{56}$ These analytical distinctions are of importance, as they allow a more general and simultaneously empirically more open understanding of modes of generalised exchange and features of social structures. ${ }^{57}$ Although there may be some empirical overlap between these different forms and features, they constitute different models (if not distinct types) of generalised exchange.

In the past few decades, the analysis of patron-client relationships, in particular the model 'neo-patrimonial' politics, has been extensively applied and developed with reference to African states. ${ }^{58}$ As Clapham makes explicit, the term 'neo-patrimonial' refers to political orders in

56 The concept of an 'addendum' is derived from C. Landé, who elaborates that “formal, explicit, institutionalized contracts do not offer an adequate explanation of the way a community works, because they do not provide for all of the needs of a community or of the individuals who enter into such contracts. Some of these must be enlivened by the superimposition upon them of voluntary relations of a more selective, flexible, intermittent and emotional sort" (Landé 1976; quoted in Eisenstadt/Roninger 1984: 49-50). What is meant with 'addendum', in other words, is not necessarily the higher premium on affective or culturally embedded exchange relations in periods of increased instrumental rationalisation, such as identified by Huntington 1969, but the enrichment of social relations by further rationalities without threatening what Gellner/Waterbury (eds.) 1975 term the dominant (in contemporary states usually: legal-bureaucratic) principle of social organisation.

57 Interestingly, African countries play a minor role in patron-client-theories of the era; for instance, Eisenstadt/Roninger 1984 only include one African country, namely Rwanda, in their discussion of in total 30 case-studies.

58 The early literature draws heavily on Weber's concept of patrimonialism (see Weber 1985). However, as, for instance, Eisenstadt/Roninger 1984 demonstrate, and Erdmann/ Engel point out explicitly (Erdmann/Engel 2006: 12, footnote 7), a specifically 'African' subtype of patrimonialism (and, by extension, neopatrimonialism) would only make sense in a comparative conceptualisation. 
which patrimonial rationales are intimately interwoven with legal-bureaucratic rationales,

a form of organisation in which relationships of a broadly patrimonial type pervade a political and administrative system which is formally constructed on legal-rational lines. Officials hold positions in bureaucratic organisations with powers which are formally defined, but exercise those powers, so far as they can, as a form not of public service but of private property (Clapham 1985: 48).59

Fully aware of the plurality of simultaneous rationales discussed above, Médard, a renowned French Africanist, goes a step further by painting the elusive and ambivalent character of a neo-patrimonial political order:

Unlike the patrimonial regime the neo-patrimonial regime hides behind a public facade which is complex and differentiated. It dissimulates the private while simulating the public. This is of course true of all political regimes and all political speeches, as neo-patrimonialism is not the monopoly of underdeveloped states. However, while in the developed states the patrimonial reality coexists with a strong institutionalization of power, in underdeveloped states it undermines the state itself (Médard 1982: 181).

Although the 'real' politics may be hidden behind a public facade, neopatrimonial politics produce and reproduce the centralisation and interdependence of socio-economic and socio-political power-political office as the 'clearing house'-which enable the patrons to materially 'feed' their clients and their clients to express political loyalty. Médard astutely observes that neo-patrimonialism reduces political resources into economic ones, for

politics becomes a kind of business with two modes of exchange: connections and money. The state is a pie that everyone greedily wants to eat. Observing these practices, however, shows that Western-style reference to ideas of public service of general interest is not entirely a mystification, as some authors assume. Truly, these concepts remain vague; they also hide specific interests, but one must acknowledge that when these values are not sufficiently internalized, this results in incongruous behaviour from the viewpoint of good administration (Médard 1982: 183). ${ }^{60}$

59 For early literature on patron-client relationships and neo-patrimonialism in Africa see also Lemarchand/Legg 1972, Theobald 1982, Joseph 1983, and the contributions in the edited volume on patronage and political power in Clapham (ed.) 1982. For a recent concise overview and differentiated analysis see Erdmann/Engel 2006.

60 The whole idea of 'nation-building' begs the question of whose nation, i.e. the interests and values of which social groups shape and participate in this process. Picking up the issue of who carries and transforms which interests, Leys dryly observes the following on 
In spite of this recognition of values informing political relations, he maintains that the core of neo-patrimonialism must be its (country-specific) politico-economic dimension: "Neo-patrimonialism is conditioned by mechanisms of production, exchange, extraction, distribution, and, eventually, accumulation of resources" (Médard 1982: 185). Echoing Scott's cry for empirical analysis, Médard also argues that neo-patrimonialism can only be understood if each of its elements (corruption, nepotism, patronage, etc.) are understood in their concrete relationship to the political regime in question. In other words, neo-patrimonial regimes, whilst characterised by certain key features, are dynamic and potentially adaptive configurations that are subject to contingency and change.

A point which has been sidelined hitherto is that neo-patrimonial practices are anchored in the social underpinnings of political authority, for by definition patronage-ties cut across the divide between political authority, social legitimacy and economic wealth. By harnessing social institutions - such as ethnically, regionally or spiritually legitimated or, indeed, constructed communities ${ }^{61}$ - political and economic power is consolidated and simultaneously elongated in its outreach. Instead of a legal-bureaucratic framework of due process, however, the medium of this relationship is the exchange of political acquiescence for state resources is a medley of particularistic and universal, public and private, formal and informal practices, the patterns of which are highly contextual. So whilst the state, or state resources, are the honey-pot for which competing groups struggle and strain, personal ties and practices interweave with impartial rules, thus creating a specifically neo-patrimonial rationality that mediates and orders the hierarchy of and integration into the political order. As in patrimonial societies, unequal relationships between individuals and groups, between patrons and clients, are the defining characteristic of such an order, but with the significant difference that

under neopatrimonialism, the distinction between the public and the private, at least formally, exists and is accepted, and public reference can be made to this distinction (it is a different matter whether this is observed or not). Neopatrimonial rule takes place within the framework of, and with

the conditions in 'new states': "Neither attitudes nor material conditions in these countries are focused on the support of a single concept of the national interest or of the official purposes of state and local officers and institutions which would promote that interest" (Leys 1965: 224).

${ }^{61}$ On the latter see the decisive works by Anderson 1983 and Hobsbawm/Ranger (eds.) 1983 . 
the claim to, legal-rational bureaucracy or 'modern' stateness (Erdmann/ Engel 2006: 18). ${ }^{62}$

In other words, the simulations and seeming incongruousness of political practices in neo-patrimonial orders observed derive their very legitimacy from their reference to distinct, albeit interwoven rationalities-or, to stay closer to the (post-)Weberian terminology, to two distinct but in this particular case intimately interwoven types of domination. ${ }^{63}$

More recently, Bratton/van der Walle (1994, 1997) have conducted seminal studies on political regimes and democratic transitions in African states, exploring the implications of neo-patrimonialism for political change. Although the context has changed dramatically-on centre stage is not the modernisation of authoritarian or soft states anymore, but their democratisation - the theoretical prerequisites of formal rationality and effective institutions are identical. Interestingly, in spite of the significant change in national and international contexts, their diagnosis of African politics is an echo of Médard:

Rather, the distinctive institutional hallmark of African regimes is neopatrimonialism. In neopatrimonial regimes, the chief executive maintains authority through personal patronage, rather than through ideology or law. As with classic patrimonialism, the right to rule is ascribed to a person rather than an office. In contemporary patrimonialism, relationships of loyalty and dependence pervade a formal political and administrative system and leaders occupy bureaucratic offices less to perform public service than to acquire personal wealth and status. The distinction between private and public interests is purposely blurred. The essence of neopatrimonialism is the award by public officials of personal favors, both within the state (notably public sector jobs) and in society (for instance, licences, contracts and projects). In return for material rewards, clients mobilize political support and refer all decisions upwards as a mark of deference to patrons. [...] Thus, personal relationships are a factor at the margin of all bureaucratic systems, but in Africa they constitute the foundation and superstructure of political institutions (Bratton/van der Walle 1992: 458-459; emphasis added). ${ }^{64}$

62 See also Gellner/Waterbury (eds.) 1975 for further analyses.

63 For a detailed contribution on the relevance of patrimonial symbols for the moral matrix of political legitimacy in Africa see Schatzberg 2001; for an elaborate discussion of neo-patrimonialism in post-Weberian terms see Erdmann/Engel 2006.

${ }_{64}$ See also Bratton/van der Walle 1997. This insight corresponds with the typology developed by Landé 1976 (quoted in Eisenstadt/Roninger 1984: footnote 40), who does not speak of personal relationships on the margin of bureaucratic systems, but as an 'addendum'. The insight is the same, namely that personal relationships constitute a subordinate politico-administrative matrix, omnipresent but not omnidominant. For contemporary theories on the importance of personal and informal relations for the institutionalisation of social interaction and reduction of social friction see Coleman 1990 or Putnam et al. 
Taking this analysis a step further, Bratton/van der Walle frame the question whether individual key actors, such as the 'big man politics' and the pattern of their political rule in African countries, ${ }^{65}$ shape the outcome of politics idiosyncratically, or whether there are deeper structural features that impact on the outcome of political transitions. Bratton/van der Walle come to the conclusion that transition processes are more contingent on the previous regime type than on other factors. According to their findings, the 'rules of the political game' structure the dynamics of the transition, even if they do not determine the outcome itself. More saliently, their findings indicate that the prospects for democracy depend on prior traditions of political pluralism. The conclusion is stark: neo-patrimonial regimes, characterised as they are by the privatisation and monopolisation of political power, inherently disable processes of democratisation and pluralisation (Bratton/van der Walle 1994: 474-480). As they contend themselves, in itself this may not be such an original insight. However, based on the premise that new modes of political behaviour require a learning process by the involved actors (and, therefore, the crucial step from 'democratisation' to democracy is only achieved once this particular internalisation and institutionalisation has taken place), Bratton/van der Walle spell out the analytical implications by linking the make-up of the previous regime with the actual dynamics unfolding during times of political change:

Our argument suggests that organizations both within and without the state, and the interaction between them, provide critical arenas for this learning. It will be difficult, that is, to institute new rules of accountability, tolerance, and participation if political parties or trade unions are missing or underdeveloped and if judicial and legislative bodies have no tradition of independence from the executive (Bratton/van der Walle 1994: 488; emphasis added).

Whilst recognising the practical importance of the informal organisation of political, social as well as economic relations, they stress the pivotal importance of formal institutions of political participation and opposition for transformation.

1993, both conceptualising in different approaches the importance of social capital for the accumulation of social cohesion, trust and knowledge exchange; or Granovetter 1985, who famously observed the 'strength of weak ties'.

65 See Médard 1982 for a key article on the phenomenon of Big Men in African states; see seminally Jackson/Rosberg $1982 \mathrm{a}$ and $1982 \mathrm{~b}$ for the meaning of personal rule in postcolonial Africa. 
Although the analysis of the political economy of corruption through the lens of neo-patrimonialism is empirically and analytically valuable to understand the concrete politico-economic institutions and their dynamics in particular countries, there are two main critiques that need to be levelled against it. The first regards scholars of neo-patrimonialism's nearly exclusive emphasis on personalistic ties permeating the state as the root cause of underdevelopment. Although neo-patrimonial and clientelistic relationships are uncontestedly a predominant structural characteristic of African states, and the theory of neo-patrimonialism has laudably heightened the theoretical as well as empirical understanding of these mechanisms, neo-patrimonial theories are constrained by its strict dichotomies of (neo-)patrimonial versus rational/legal principles and informal versus formal principles. Neglected here are the highly creative processes of adaptation and assimilation that this 'informalisation' of rationalities and dominance allow.

The specifically modern social imaginaries of neo-patrimonial states are both more diverse as well as more constrained than in legal-bureaucratic states. To use a term elaborated by Charles Taylor, the 'social imaginaries', i.e. the background images that inform the "implicit grasp of social space" (Taylor 2004: 26), are key to a socially and individually visceral understanding of the norms underlying social practice. They are also key to a sense of what makes these norms realisable. However, as Taylor demonstrates, such imaginaries are not unchanging, underlying as they do dynamics of appropriation and change. Initially, specific moral orders (such as, for instance, the legal-rational or 'modern' state) may be idealised, but this idealisation itself leads to complex imaginaries that are associated with specific and generic social practices. Taylor himself observes that this process is frequently dynamic, both recreating as well as creating a social order that is "in part traditional but often transformed by the contact" (Taylor 2004: 19). Emerging forms of social imaginary in times of social change, hence, are not necessarily uniform, nor need to be applied and appropriated uniformly; on the contrary, often new principles and norms are introduced only on certain levels "while leaving other niches untouched" (Taylor 2004: 146). ${ }^{66}$

66 Classically, this process of uneven penetration of society by enlightened and legalrational values has been demonstrated by scholars such as Durkheim 1960 or Weber 1985, 2004, analysing the transformations to specifically modern states, economies and societies. Taylor discusses it inter alia in terms of contemporary societies, e.g. with regard to issues of suffrage or minority rights (see Taylor 2004). 
Applied to the political order in Africa, the social imaginaries that penetrate and inform the social realities of African states are evidently derived from both patrimonial as well as from legal-bureaucratic orders; a hybridity which, on the one hand, opens up spaces of creativity and negotiation on prevailing norms (unlike the 'iron cage' of legal-bureaucratic domination diagnosed by Max Weber), but on the other hand also imposes particularistic constraints on the scope and type of action at the disposition of social actors. The constraints derive precisely from the seeming pluralism of frames of reference: the characteristic ambiguity of neo-patrimonial orders with regard to the prevailing dominant order in specific moments does not necessarily open up creative spaces. In practice it seems to primarily open up a wider spectrum of sanctions available to patrons, who can draw on both patrimonial as well on legal-bureaucratic norms and corresponding disciplinary measures, with a degree of arbitrariness that is directly correlated to the relative powerlessness of the clients. So whereas in Western history the specifically modern social imaginary lead to the primacy of categorical relations (to use a term by Taylor) and an emancipation from ascribed or 'traditional' relations (albeit unevenly), the process in African countries is dissimilar: the 'contact' of modern social imagery with the social, cultural and economic realities has led to a relative disempowerment and disenfranchisement of people and a transformation of 'ascribed' identies. ${ }^{67}$

A second critique of the neo-patrimonial state is levelled against a different dimension of the concept, namely against the invariant frame of reference of such an approach: the image of a Weberian state, portrayed implicitly as an autonomous, unchanging and coherent body of space and norms. Viewed through the lens of a legal-bureaucratic state any leakage of other rationalities and practices into this bounded public sphere is considered deviant - although of course the ideal-type of a legalbureaucratic state is just that, an ideal-type and not social reality. ${ }^{68}$ The merit of neo-patrimonial theories is that they, in contrast to the more

67 In contemporary African studies the focus on such invisible dynamics and creativity has gained renewed traction from an agency perspective, highlighting the surprisingly successful and resourceful survival and coping strategies of actors in sometimes extreme situations of marginalisation and destitution. For an influential general theoretical contribution, see Long 2001; for a recent contribution with an African focus see Chabal et al. 2007; for a critique with regard to the underlying 'overoptimism' of such agency-centered theories of African societies see also Chabal 2009.

68 For an influential theorisation of the heterogeneity of contemporary states see Migdal 2001. 
simplistic modernisation theories, conceptualise political deviance as an order sui generis, but the normative judgement deriving from the modern ideal-type is not suspended. On the contrary it serves to sharpen the contours of the 'deviant' (patrimonial) order. More interesting theoretical approaches undercut such limiting and normative dichotomies, exploring 'the state' as part of a field populated by multiple actors, practices and framing matrixes, in which both the images as well as the practices produced in these fields "can be overlapping or reinforcing, or contradictory or mutually destructive" (Migdal 2001: 16), ${ }^{69}$ raising issues I shall return to further down.

The main conclusion emerging from neo-patrimonial theories is that evidently new values and rules are not consolidated automatically: the internalisation of values that provide a frame of orientation for everyday attitudes and practices, normative prescriptions on the 'right' behaviour, and correspondingly a regime of social and legal sanctions that regulate and control such practices underlie complex contingencies. Looking at more iterated patterns, the impact of new rules and resources on configurations of power and political order is even more unpredictable. The key question is what social practices do these social imaginaries lead to, what new, adapted, appropriated, or, indeed, unchanged figurations of social and political order? For if, as the studies on democratisation show in an exemplary fashion, the formal, democratic transformation of neopatrimonial regimes merely leads to the consolidation or even radicalisation of neo-patrimonialism (albeit now in a formally democratic guise), is the quest for the identification emancipatory actors and practices not futile? ${ }^{70}$ How should the implored values of 'accountability, tolerance, and

69 The approach of 'state in society' developed by Midgal, who draws on Weber, Shils, Bourdieu and (with critical qualifications) Foucault in his elaboration of a more dynamic concept of 'the state'. The lynchpin is his highly pertinent definition of the "state as a field of power marked by the use and threat of violence and shaped by (1) the image of a coherent, controlling organization in a territory, which is representative of the people bounded by that territory, and (2) the actual practices of its multiple parts" (Migdal 2001: 16, emphasis in original). The key point is the while "the image of the state implies a single morality, one standard way, indeed right way, of doing things, practices denote multiple types of performance and, possibly, some contention over what is the right way to act" (Migdal 2001: 19; emphasis in original). Although arguably the dichotomy between image and practice is not as pronounced as implied in Migdal's twofold definition (see, for instance, Taylor 2004), his 'state in society' approach provides a sophisticated and useful analysis of the complexities of what conventionally is so bluntly termed 'public-private' relationships.

70 This may also be due to the naïvety of Africanists, who tend to disregard sophisticated theories on political and economic change (e.g. Schumpeter 1993; Polanyi 1957). 
participation' (Bratton/van der Walle 1992: 488) evolve, how do the 'political parties or trade unions' (Bratton/van der Walle 1992: 488) emerge. ${ }^{71} \mathrm{In}$ other words, where do the value systems and social actors emanate from to carry, shape and institutionalise such a transition, if evidently the blurring of the private and public boundaries are a defining feature of African societies?

In a seminal article published in the mid-sixties, Leys discussed the identical problem of a "corrupted society" (Leys 1965: 228) in new African states, and came up with a highly Weberian solution:

There are perfectly plain differences to be seen between one developing nation and another in terms of the public spirit and devotion to duty shown by their elites, and the idea of a society economically stagnating in the grips of a self-seeking and corrupt élite is not a pure fantasy. The line of escape is also fairly clear. Typically, a nucleus of 'puritans' - drawn from groups of such as an independent business class, professional groups, or small farmers - begins to exercise effective pressure to apply the official but disregarded public code of ethics (Leys 1965: 229).

In the meantime, Leys' cautious strand of hope with regard to 'progressive'-here: in Weberian tradition 'puritan'_forces as well as the more confident predictions by other authors about the facilitative function of corruption have been proven wrong by the political and economic reality of subsequent decades. With the benefit of hindsight and even after the democratic revolution in Africa the conclusions reached by Bratton/ van der Walle have been overtaken by the realities of seemingly 'unproblematic' countries such as Kenya or the Côte d'Ivoire. Ultimately, in both cases their political break-downs can also be traced back to the dominating politics of neo-patrimonialism and social cleavages entrenched by particularistic and vertical modes of redistribution. ${ }^{72}$

Hence, given the historicity and theoretically contested universality of the Western state, the most prominent weakness may well be the

I maintain, however, with Rueschemeyer and his fellow authors in their seminal study on the relationship between capitalism and democracy, that "it is power relations that most importantly determine whether democracy can emerge, stabilize and then maintain itself even in the face of adverse conditions" (Rueschemeyer et al. 1992: 5).

${ }^{71}$ The quotes of Bratton/van der Walle 1992 are used as a pars pro toto that crystallise Africa's key 'absences' identified in the scholarly and developmental literature-and at the same time constituting the key solutions identified for its development (for many others: Hyden 2006).

${ }^{72}$ For a political economy of ethnicity see Berman (2004), Berman et al. (2004); for a highly insightful book on Kenya illustrating this point graphically see Wrong 2009. 
precedence accorded to the normative distinctions and elevations inherent in state definitions and imaginaries that even differentiated and sophisticated neo-patrimonial approaches fall prey to. The political economy of corruption is hobbled to its inherent benchmark, the deeply ingrained culture of public administration in Western liberal-democratic states. The conceptual dichotomy of 'modern' bureaucratic-legal and 'traditional' patrimonial order, ${ }^{73}$ on which the concept by definition rests, makes it if not blind then blinkered to new formations and figurations of social order that do not necessarily reproduce this dichotomy.

Before, however, we turn to political orders that go beyond such established frameworks, a second line of thought about politics and boundaries in Africa needs to be explored. This takes us to a hitherto underexplored dimension of corruption: the cultural embeddedness of social and political practices observed in the introductory remarks. Networks of patronage and clientelism are not exclusively informed by power relations, but evidently have specifically cultural roots; they are nurtured and legitimised by specific social values, practices and norms. Cartier-Bresson terms this phenomenon aptly "social exchange corruption" (Cartier-Bresson 1997: 466), where corruption is organised by social networks and becomes institutionalised through long-term relationships and community-like structures based on trust, reciprocity and solidarity. ${ }^{74}$ It is these relationships and their structuring principles that need to be understood more clearly to render a more complete picture of the political economy of corruption, which shall be sketched out in the following section.

\section{The Moral Economy of Corruption: Values and Practices}

As was shown above, the early debate on corruption and development already features a broader socio-cultural understanding of corruption. ${ }^{75}$ The roots of such a conceptualisation can be found in classic political economy that put the relationship between moral order, economic

73 See Rueschemeyer et al. 1992 for an excellent survey and analysis of the historical and sociological context of this development.

74 Here, Cartier-Bresson 1997 leans heavily on the seminal insights of Granovetter 1985.

75 One could argue that this was primarily due to the analytic frame of reference based on the dichotomy between traditional and modern societies; by definition, the undifferentiated, static features of traditional societies in modernising states could only be captured with reference to social, cultural and religious determinants. 
practices, and the social good on centre stage. ${ }^{76}$ In the last century, the embeddedness of economic relations in a socio-moral matrix was famously profiled by Karl Polanyi, who in his opus magnum "The Great Transformation" (1957 [1944]) traced the ways in which capitalist economies are no longer embedded in a social and moral order; the ways that such economies no longer rely on social modes of regulation to control modes and norms of economic conduct, but on the contrary, have produced a society which operates merely "as an adjunct to the market", as he puts it (Polyani 1957: 57). Still, the concept of a moral economy, i.e. a socially embedded economy, where social norms and values are not just internal to economic practices (in the sense that these are historical and cultural products), but provide the prime frame of economic relations, plays a key reference point in his analysis of the commodification of society and the self-regulation of markets.

In development studies, the concept of a 'moral economy' is closely associated with Scott's seminal study on modes of production in rural South-East Asia (Scott 1976). Scott's theoretical innovation was to capture the powerful social principles of reciprocity and obligations as economically rational logics of subsistence. The 'ethics of subsistence' he describes is placed in a context of high insecurity, minimal resources, and little room to manoeuvre for individual peasants and peasant families (Scott 1976: 13-14); the objective and premise of his study is "that we may learn more about the politics of the peasants by asking not merely how poor they are but also how precarious their livelihood is" (Scott 1976: 34$){ }^{77}$ The novelty of Scott's approach was the empirical recognition and analytical inclusion of non-economic factors to explain economic behaviour; not by reducing his theory to cultural determinants, but by embedding it in a social context. ${ }^{78}$ Not long after, Hyden (1980) coined the term 'economy of

76 Classically see Adam Smith, who analyses the ways economic relations are informed by moral 'sentiments' in the sense of values (and the rationales under which these are overridden) in his two main publications, the "Theory of Moral Sentiments" (1759) and the "Wealth of Nations" (1776). See also for an earlier and influential contribution Adam Ferguson's "Essay on the History of Civil Society", first published in 1767 (see Ferguson 1995).

77 Scott's study begins by analysing the meaning of subsistence 'ethic' for peasant economies, which he explores right to its logical and significant end by applying it also to peasant politics and, saliently, the question of peasant rebellion; essentially and highly politically, Scott tries to understand the dynamics of continuity and change in the agrarian order.

78 This more differentiated understanding of economic theory, that conceptualises economic behaviour in a socio-cultural environment rose to glory under the label 'neoinstitutional economics' in the late eighties through renowned scholars such as Elinor 
affection' ${ }^{79}$ exploring the particular logics of peasant production in rural East Africa that are based on affective ties and solidarity. ${ }^{80}$ Here, analogous to Scott's study, the investment in social relations is more important to the generation of status and security than the investment in means of production. ${ }^{81}$

It is this blind spot comprising the socio-moral framing of certain practices that Olivier de Sardan (1999) attempts to illuminate by conceptualising corruption in Africa in terms of a moral economy. The emphasis is on 'moral', focusing on the morality framing corrupt practices that are rarely found in other approaches. In his words, the

social mechanisms of corruption are scarcely explored, nor are its processes of legitimation seen from the actors' point of view. This is why this article uses the term: moral economy, which may appear surprising when attached to a term as unanimously stigmatised as amoral or immoral. The intention here is to insist on as subtle as possible a restitution of the value systems

Ostrom (1988) or Douglass North (1990). Following excerpt may illustrate this paradigmatic shift from the neo-classical model of rational, distanced individuals to the institutional approach of embedded actors: "The political realm is not a world apart from the economic realm, the religious realm, or the social realm. Families are key producing, trading, consuming, educational, and self-governing units in any society. They sustain an intergenerational cycle of life that is ordered in relation to conceptions and practices that have ethical and religious significance. Societies get put together as complex configurations of human relationships" (Ostrom 1988: 445).

79 However, for our purposes Hyden's term is more misleading than Scott's, for the constraints and pressures of subsistence produce a particular moral matrix which have little to do with affection. The economy of affection maximises security, so that 'affection' must not be understood in a subjective sense, but in a normative sense. Hence, analogous to the 'moral' of peasant economy, to a certain degree 'affection' is objectified to secure economic survival. The approach developed by Scott, on the other hand, is based on a clear theoretical frame of reference with a hermeneutic focus on the specific individual and communal rationality inherent in a particular socio-economic context.

80 For a critique of Hyden's concept see Hauck 2001: 201-205.

81 One of the characteristics of such affective, reciprocal economic transactions analysed by Hyden is the virtual inexistence of conflictual power relations that determine market economic transactions. In the economy of affection, by definition, irrespective of the intended gain or distribution of benefits, social relations within the same kin or community must be harmonious, implying on the other hand that conflicts are more likely to emerge between different communities than within the same social group (Hyden 1980). As Myrdal (1968) amongst others already observed, particular modes of (peasant) socioeconomic organisation are linked to particular modes of social identification and conflict resolution, which have strong repercussions on the way that communities interact with other communities and, centrally, with the nation-state as a whole. Hyden's core interest lies here, in the role of the state as a transformative power vis-à-vis such a moral matrix framing economic relations, whereas Scott is more interested in the conditions of social action by peasants. 
and cultural codes, which permit a justification of corruption by those who practice it (Olivier de Sardan 1999: 25). ${ }^{82}$

Olivier de Sardan's central question revolves around the generalisation, normalisation and banalisation of corruption in contemporary Africa. With a set of discerning hypotheses and facilitating 'logics of corruption', he shows how social and cultural norms frame the arena in which actors can and do operate in contemporary Africa. He lays bare the routine practice of corruption, or what he-similar to Cartier-Bresson's notion of the social exchange of corruption-terms the 'corruption complex', i.e. the broad practice of illicit deeds in sweeping contradiction to the official ethics of 'public property' or 'public service' (Olivier de Sardan 1999: 28-30). Although these practices are only in part legally corrupt, their illicit character is still pivotal for a meaningful understanding of the problem of corruption in contemporary, post-colonial African societies.

Interestingly, Olivier de Sardan takes the discrepancy between 'formal' and 'practical' norms as a frame of reference-in his view, "the core of the sociological problem of corruption is to be situated in the distance between juridical condemnation of certain practices and their frequency, their banalisation or indeed their cultural legitimacy" (Olivier de Sardan 1999: 29).$^{83}$ From his perspective, the explanandum must include the social reality of everyday behaviour, "in order to consider what these various practices have in common, what affinities link them together, and to what extent they enter the same fabric of customary social norms and attitudes" (Olivier de Sardan 1999: 28). Based on the analysis of this sociomoral fabric, he diagnoses a "schizophrenic situation" (Olivier de Sardan 1999: 48), where the professional and administrative legitimacy of civil servants is derived from a more or less completely contradictory set of values than their social legitimacy.

What is new about this diagnosis is the light it sheds the complex cultural embeddedness of corruption. Olivier de Sardan distinguishes between general theses on the institutional framework of corruption in Africa, such as the general discourse on corruption and patterns of its stigmatisation and routinisation, on the one hand, and identifying on the other hand its socio-cultural logics, such as solidarity and networks of

\footnotetext{
${ }^{82}$ However, Olivier de Sardan does clearly not have an interest in the economy of corruption, i.e. the relations of production, such as Scott or Hyden put in the centre of their enquiry.

${ }^{83}$ For a critique of this view, see the last section in this chapter.
} 
the people, the predatory authority of the elites or continual negotiation. These logics are compounded by transcending and 'facilitating' multipliers particular to African societies. Firstly, a sense of shame: on the one hand, shame to fail to deliver the spoils of the office to those who socially feel entitled to a part; on the other hand shame to 'betray' the practices of corrupt colleagues. Secondly, the 'over-monetarisation' of social relations, with money playing a permanent and central role even in (what would be considered in Western societies) the most private of social relations. Within this densely woven fabric, corruption becomes a cultural imperative framed by socio-economic determinants.

The analysis Olivier de Sardan offers is remarkably insightful, illuminating diverse facets of the corruption complex. Rather disappointingly, he then reaches a surprisingly simplistic conclusion, namely that the crux of Africa lies in the "glaring discrepancy" (Olivier de Sardan 1999: 47) between the norms of the public service and legal definitions of corruption with the predominant socio-cultural logics. More direly, "it would seem that the effect of acquired habits and the normalisation of commonplace practices renders the situation more or less irreversible." All he leaves the reader with is "the general feeling of helplessness in the face of an infernal mechanism" (Olivier de Sardan 1999: 48), and an outlook which is dismally identical to the finding that Colin Leys came to over 30 years earlier ${ }^{84}$ that the "development of movements of a 'puritanical' tendency, intended to bring about a reform of public morals [...] may be among the ultimate means, in the absence of an improbable self-reformation of the political elites, to attempt to change the present course of affairs. Any 'anticorruption' policy must face up to these realities" (Olivier de Sardan 1999: 48).

In other words, although not only the understanding and conceptualisation of corruption has come a considerable way since the height of

84 See Leys 1965, in particular his doubts with regard to the development of such a "nucleus of 'puritans'" (Leys 1965: 229) as a precondition for the development of a public morality - given the lack of appropriate conditions in the newly independent African states, not least "the wealth accumulated improperly by the top élite" that is "solely motivated by the hope of personal gain" (Leys 1965: 229). Looking at the extent of grand corruption in Africa in the past decades, his analysis pre-empted the trends later captured in terms of kleptocracy, predation and criminalisation (see, for instance, Bayart et al. 1999; for an excellent documentary account of kleptocracy in the former Zaïre under Mobutu Sese Seko see Wrong 2002; for a detailed account of grand corruption from a whistleblowers perspective in Kenya under Kibaki see Wrong 2009; or for a knowledgeable dissection of the role international business in grand corruption see pioneeringly Moodie-Stuart 1996 and recently Baker 2005). 
modernisation theories, but also the understanding and empirical studies of 'development', the analytical implications of a theory of corruption jumps back to square one. The paltry product of Olivier de Sardan's innovative emic view is the vague notion of induced, disembedded development of socio-moral movements to change the present course of affairs. ${ }^{85}$ Such a statement begs the question from where such puritanical movements should evolve from, if, according to his analysis, social practices are too sedimented for change. In spite of his definitional reference to the legal-bureaucratic institutional framework, he too falls prey to the fruitless opposition between legal-bureaucratic norms on one side and social practices on the other side, thereby rendering the exploration of the (potentially creative) dynamics between social practices, ingrained values and official norms impossible. ${ }^{86}$

In conclusion, what the debate on the moral and political economy shows is that theoretical understanding as well as the implementation of anti-corruption policies require more differentiated empirical studies to shed light on the "critical arenas for learning" (Bratton/van der Walle 1994: 488), studies that capture the processes framing the values that serve as orientation to social practice, norms that are endowed with social significance (and the actual power to sanction), and institutions with the

85 Olivier de Sardan is unfortunately not alone here. As was shown in the preceding sections, this point is made consistently by scholars of Africa from all disciplines. Most analyses end in a highly Weberian 'solution', disregarding more sophisticated social-scientific literature as well as studies of the East Asian 'miracles'. Consider, for instance, Hyden's surprisingly simplistic statement on the type of government prevailing in African states and the type seen to be necessary for the pursuit of the public good: "Every country in the world that is now developed-or succeeding in getting out of poverty-has been forced to reduce or eliminate informal practices such as nepotism, spoils, and similar discretionary uses of public authority. What remains to be done in African countries, therefore, is by no means unique. What is possibly exceptional is the extent to which these problems appear intractable. They may, therefore, call for bolder thinking [...]. A policy government is committed to providing and implementing public goals that have been duly approved by institutions with legitimate authority to do so. There is a clear separation between official and personal and the distinction between public and private matters. That means that employees have a self-binding commitment to an organizational mission, its objectives, and the specific tasks associated with particular roles that they play. They are driven by work related goals, not those that may arise during the workday stemming from the personal problems of one's relatives or friends. In short, there is a work discipline that precludes distractions. On top of that, in the best cases, there is a professional pride in work and achievement." (Hyden 2006: 266).

86 Not least, a more explicit reference to the economics of corruption is also lacking, beginning with (economic) survival strategies and ending with the globalisation of corrupt economic opportunities (e.g. capital-flight, money-laundering, etc.). For a discussion see Mény 1996. 
capacity and mandate to provide public goods. 'Getting institutions right' was the implicit approach of the good governance agenda, which has not achieved its goal of strengthening the effectiveness and accountability of states; 'getting values right' is inherently fraught with conceptual and hence also empirical problems - so what remains? Although Olivier de Sardan succeeds in sketching a dense and 'daily' picture of the corruption complex, he flags at the dire consequence of his analysis. Left only with "the general feeling of helplessness in the face of an infernal mechanism" (Olivier de Sardan 1999: 48), he struggles to find a flicker of enlightened hope. Whether political realities in Africa are really framed by such an infernal mechanism is a question I shall return to in Part B. First, however, pursuing the reconstruction of pivotal theories on political order and corruption in Africa, another angle shall be illuminated, Here, instead of seeking the way out of such 'infernal mechanisms', perhaps the political as well as moral economy of corruption should be understood as exactly that: a political order sui generis, shaped by own and unique patterns linking social actors to rules and resources.

\section{The Order of Disorder: Power, Authority and Accumulation}

As we have seen, conventional wisdom has it that political order in Africa is characterised by a whole shopping list of patrimonial networks and personalistic, particularistic and ascriptive politics, symptom of the pervasive blurring between the public and the private sphere. The 'thoroughly corrupted society' discussed by Leys (1965) as a remote likelihood over forty years ago, seems to have become reality in many African states, leading in many cases to complete economic, social and political breakdowns-not only a failure of development in terms of social and economic indicators, ${ }^{87}$ but also a failure of 'modernisation', of the institutionalisation of the

87 This popular perception of Africa is substantiated by development indicators. For instance, in the latest Human Development Report 21 out of 23 countries classified with 'Low Human Development' are African countries (see UNDP 2009; the report and the indicators are available online under http://hdr.undp.org/en/reports/global/hdr2oog/; last accessed 25 March 2010). A more polemic index of failed states underlines the prominence of African countries in terms of social, political and economic disintegration, with 11 African countries ranked in the first 20 of the Failed States Index 2009, including intuitively implausible ones such as Ethiopia (rank 16) and Nigeria (rank 15). The index is available under http://www.foreignpolicy.com/articles/2009/06/22/2009_failed_states_ index_interactive_map_and_rankings (last accessed 25 March 2010). 
modern state. Rapaciousness, corruption and inefficiency seem to have become the hallmark of modern African politics, again after the retreat of the Third Wave. Maybe the merit of the concept of neo-patrimonialism is the fact that, to a certain degree, it reinserts the historical context into politics. It shows how the 'modern' state is appropriated by private interests, an interaction which is strongly couched in economic, social as well as symbolic (ethnic, religious, magical, etc.) terms. Of course, access to and (re-)distribution of public resources are the hinges this relationship swing on, operating not along the distinction but in the intersection and interweaving of private and public spheres. The 'incomplete' institutionalisation of the state, in terms of its practical elevation over other structuring principles, is in fact the stuff of these relations of enrichment, reciprocity and mobility, the umbilical cord that feeds patrons and clients.

But the question remains: how can the ambivalence of the public sphere, the intertwining of the formal and informal, the self-enrichment and even vicious predation by African elites be explained? The core of the problem is the framing of the fields of power that characterise African societies. In spite of the African state's apparent weakness in terms of capacity on the one hand, and apparent hegemony in terms of repression on the other hand, power in Africa is represented by a specific, nonWestern relationship to the state, oscillating between paradoxes. In Aké's forceful diagnosis:

The distinguishing characteristic of the state in Africa, however, is that it has little autonomy. This is a legacy of colonialism [...]. Colonial politics was not about good governance but about the resolution of two exclusive claims to rulership; it was a struggle to capture the state and press it into the service of the captor. [...] The [postcolonial] state is in effect privatised: it remains an enormous force but no longer a public force: no longer a reassuring presence guaranteeing the rule of law but a formidable threat to all except the few who control it, actually encouraging lawlessness and with little capacity to mediate conflicts in society. Politics in Africa has been shaped by this character of the African state. It is mainly about access to state power and the goals of political struggle are the capture of an all-powerful state, which the winner can use as he or she pleases. The spoils, and the losses, are total. African politics therefore puts a very high premium on power. [...] In this type of politics, violence and instability are endemic, with anarchy lurking just below the surface. Despite the enormous power of the state, a political order does not emerge (Aké 1996: 73; emphasis added).

As will be discussed in more detail in this section, arguably the politics that Aké diagnoses do depict the emergence of political order, albeit not one based on the rule of law or democratic values. But the politics that 
Aké and many other renowned Africanists ${ }^{88}$ evoke circumscribe struggles in African politics as particularistic, exclusionary and discrete, with political power translating into personal and/or communal economic wealth and social prestige, and few if any mechanisms of integration into political order that reach out beyond bounded groups. The radical shifts in deterritorialisation of economic relationships and of political authority of the past three decades have only exacerbated the issues. In an analysis of the external dimension sustaining and radicalising political orders that do not provide order, Mbembe in his study of the postcolony (Mbembe 2002) captures accelerating transnational factors:

Millions of people have been deprived of jobs, food and shelter and are now reduced to struggling for daily survival. Instead of curbing the corruption of local elites, the brutality of the international system has increased their greed and carelessness. Under the pretext of privatization, looting has become a norm as well as a cultural practice. Partial democratization under conditions of structural adjustment has opened the way for the privatization of violence..$^{89}$

Under these circumstances of confrontational politics, scarce resources and worn social cohesion, the deregulation, privatisation and democratisation of African states of the past decade have led not to political and economic empowerment and engagement of society, but to the polarisation of the political order. Instead of achieving societal transformation, the post-colonial state of Africa has resulted in socio-economic stalling, political uncertainty and social conflict, leading to persistently high levels of social, political and economic disempowerment. At the end of the Millennium, fuelled by the high hopes whipped up during the 'winds of change', ${ }^{90}$

88 See, for instance, the excellent volumes edited by Chazan et al. (eds.) 1988, Rothchild/Chazan (eds.) 1988 or Gordon/Gordon (eds.) 1992; further selected and influential theories can be found, chronologically, in Bayart 1989; Chabal 1992, Bayart et al. 1999; Chabal/Daloz 1999; Herbst 2000; Mbembe 2002; Hyden 2006; or Chabal 2009.

89 This quote by Achille Mbembe in an interview with Christian Hoeller (editor springerin) was first published in springerin 3 (2002). The excerpt here is drawn from the online version on H-Africa under http://h-net.msu.edu/cgi-bin/logbrowse.pl?trx=vx\&list=H-Africa\& month $=0210 \&$ week=b\&msg=MvoarOWtxoQHDYAU\%2Buy4IQ\&user $=\& p w=$ (last accessed 25 March 2010).

90 In an interesting observation, Clapham notes that although the 'winds of change' swept through Africa as well as Eastern Europe and Central Asia, just looking at the territorial structure Africa remained virtually untouched-a strong indication, in his opinion, that even oppositional and 'new' African politicians are deeply reluctant to articulate any alternative to the post-colonial state (Clapham 1996). See also Herbst 2000 on the importance of the political geography and the political function of 'hard borders' of African states. 
not the image of soft states or personal rule ${ }^{91}$ in Africa shape scholarly and popular discourses, but the image of the 'failed state'. ${ }^{92}$ Corruption here takes on a strangely hybrid guise between socio-political engagement and disengagement: although the political disengagement becomes apparent through the informalisation and illegality of corrupt practices, the systematic abuse of public funds, symbols or offices for personal or factionary interests actually serve to enhance the importance and authority of the public realm.

Against this backdrop of, one is tempted to say, the normalisation of (traits of) state failure, possibly the tables should be turned by viewing African states not as a failed or weak or soft states, but on the contrary as a successful adaptation and re-appropriation of the Western state to the African context. Here, the 'historicity', the uniqueness of the post-colonial African state is the theoretical point of departure. In distinction to the scholars such as Huntington or Scott, who were interested mainly in processes and structures framing political assimilation and integration, Bayart (1993) chooses a more archaeological and less predictive approach. What he observes is a 'hybrid state', a state in which the mix between Western organisation and norms of public institutions introduced by the colonial state and their amalgamation by local socio-political practices produces a distinct and different African state in its own right. What neo-patrimonialism already identifies, namely that in principle mutually exclusive logics, such as the formal and informal, the modern and the traditional, the public and the private, are intimately intertwined in African politics; what is novel about Bayart's view is that far from being dysfunctional, such a state is portrayed as an integrative force, the climbing frame of rhizomatically linked interests. The 'reciprocal assimilation of elites', i.e. the historically grounded collaboration between elites to secure access to national and international resources in a process of 'extraversion', is the mechanism through which the hybrid state reproduces itself. ${ }^{93}$ This is not to say

91 For the term 'soft state' see seminally Migdal 1968; for a pivotal contribution on personal rule in Africa see Jackson/Rosberg 1982.

92 It is no coincidence that seminal contributions on the 'failure' of the African state emerged in the mid-nineties. Consider the contributions in Wunsch/Olowu (eds.) 1995 . Zartmann (ed.) 1995, Joseph (ed.) 1999, and Rotberg (ed.) 2003, 2004. This discourse was compounded in the wake of $9 / 11$ and the geo-political discourse on terrorism and state failure. Hence the title of Robert Rotberg's edited volume "State Failure and State Weakness in a Time of Terror" (Rotberg (ed.) 2003). Tellingly, the annual Index on State Failure was first published in 2005 by the Fund for Peace and Foreign Policy (see http://www.foreignpolicy .com/articles/2009/06/22/the_2009_failed_states_index; last accessed 25 March 2010).

93 See Bayart 2000 on the characteristics and history of African extraversion. 
that the integrative force of the state furthers its stability or effectiveness; on the contrary, the state is merely the trough of the 'politics of the belly', i.e. the relentless pursuit of wealth, status, prestige by the elites, that enables them to further their own interest and continue internal competition. ${ }^{94}$ 'Political order' in an African context, therefore, is not produced to serve or define the public interest or to mediate conflict, but to manage the politics of the belly, the political struggle to gain access to state power and therefore to personal and communal enrichment. ${ }^{95}$

More recently, Bayart, together with co-authors Ellis and Hibou (Bayart et al. 1999), argues that African politics are currently undergoing a fundamental change in their mode of governance, formerly characterised by such politics of the belly. ${ }^{96}$ Dramatically described, a process of criminalisation, distinct from earlier forms of corruption and predation, is increasingly advancing to become the main feature of African states. Large-scale, organised economic delinquency (i.e. smuggling or fraud) as well as the spread of illegitimate use of violence have become intimately and routinely linked to the exercise of politics. The authors underline that this

94 What Bayart offers us is the 'true historicity' (Bayart 1993: 5) of African politics, a realistic account of what is happening in Africa without the claim or the attempt to practically change anything or offer advice for how such change should come about. For a critique of Bayart's concept see Leys 1994.

95 Schatzberg has provided perhaps the most detailed analysis of the cultural legitimisation underlying such metaphors, showing that "power in middle Africa has much to do with 'eating' (in both literal and figurative sense) as well as with other forms of consumption. The second premise of the moral matrix thus indicates that while the father-chief may eat', and even eat well, there are nevertheless limits placed on how much he can and should consume. In a sense, this premise deals with the imprecise frontier between an acceptable appetite and political corruption. In a rough-and-ready calculus of legitimacy, the first and second premises will probably vary directly most of the time. In other works, the more the people have to eat (the better are the general economic conditions), the lager will be the permissible range of chiefly or presidential appetite. But if the people begin to go hungry, if economic conditions deteriorate, then appetites the citizenry might once have tolerated in good times will no longer be perceived as falling within the prerogative of the father-chief. It is also worth noting that throughout middle Africa the language of corruption is often related to the language of food: 'madesu ya bana' (beans for the children), and 'un petit quelque chose à manger' (a little something to eat) in Zaïre; as well as the ubiquitous East African equivalent, 'chai' (tea). Similarly, in Tanzania during the 1980s and 1990s many folds came to believe that their leaders had 'eaten' too much, and there was a consequent corollary that their legitimacy had declined apace (Schatzberg 2001: 26; footnotes referenced in original omitted).

96 Although the authors are at pains to distinguish the 'criminalisation of the state' from the politics of the belly, they emphasise that this transformation is best viewed "in the light of historical continuity" (Bayart et al. 1999: 30), not least because of the diversity and specificity of African states and societies. 
is a nascent, uneven tendency that can be pointedly observed in various contexts, but which is not yet a universal hallmark of African politics.

It must be said that the multiplication of conflicts, the main political logic of which is simple predation and which tend to be accompanied by a growing insertion in the international economy of illegality, $[. .$.$] the spread of a$ culture of institutional neglect, systematic plunder of the national economy and the uncontrolled privatization of the state [...] all suggest that a slide towards criminalization throughout the sub-continent is a strong probability (Bayart et al. 1999: 30).

In their view, the reframing of the political field and the emerging or, as it were, consolidated types of what Olivier de Sardan termed 'predatory authority' and here is depicted as coercion stripped bare of social legitimacy has been perpetuated by the structural privatisation of the state and the erosion of public authority; however, the tangled, underground roots of the rhizome state are becoming increasingly intermeshed with criminal, illegal and, in certain areas of trade such as human trafficking and armed conflicts, even illegitimate structures. The 'shadow state' (Reno 1995) is changing its spots: whereas before, generally speaking, African politics was a function of "the management of factional intrigues for personal interest" (Bayart et al. 1999: 21), the "relationship between accumulation and power is henceforth situated in a context of internationalization and of the growth of organized crime on a probably unprecedented scale" (Bayart et al. 1999: 9). Intriguingly, in spite of the emphatic recognition of the historicity and specificity of African politics, the authors firmly anchor the definition of 'criminalization' in 'Western', universal standards of international law. Echoing other influential authors, the distance between internationally accepted (legal) norms of political order and actual political practices measures the degree of criminalization, consequently defining such international norms as benchmarks of legality. ${ }^{97}$ The central question raised in their approach is not so much the fact that the criminalisation of the African state is on the rise-a process already treated

97 The authors "regard as criminal those political, social and economic practices which are the object of a 'primary criminalization' either by the laws and other texts of the states under discussion or, more particularly, in international law, or according to international organisations or acknowledged guardians of international morality, and especially the financial and economic morality which accompanies the current trend towards the globalization of the economy" (Bayart et al. 1999: 15). As can be deduced from this definition, Bayart et al. are well aware of the cultural and normative arenas in which such notions are framed. However, as, for instance, Migdal (2001: 19) critiques, their approach still leads to an unreflected elevation of one set of standards over another. 
in theories of neo-patrimonialism - but the question of radically changing terms of legitimacy. Whereas before illegal and even criminal acts committed within the logics of neo-patrimonial relations were politically legitimate (at least for the beneficiaries), the frame of political reference seems to be hardening. Ultimately, what Bayart and his fellow authors propose is the re-circumscription of political 'order' in Africa; the politics of the belly and the politics of extraversion are mutating from the 'merely' informal or personal sphere to a highly organised, clearly illegal and frequently illegitimate dimension. In fact, this hypothesis leads the authors to contemplate the changing nature of political order in general:

In effect, one may wonder whether the phenomenon which we describe as criminalization is not best considered as a qualitative change which is transforming the overall manner in which whole societies and the international system of diplomacy and commerce are organized, by changing the balance of forces between fundamental determinants of any political order: power, accumulation and the exercise of violence (Bayart et al. 1999: 18).

In a nutshell, profound changes on the national and international stage have led to mutating determinants and the body politic in Africa. As a consequence, the understanding of political legitimacy lies wide open in Africa-and, by implication, elsewhere. The criminalisation of the state implies that the moral economy of corruption, embedded as it is in socioculturally legitimising logics, is ruptured; that the acquiescence of the population is framed by violence, only partially embedded in functional exchange relationships, such as between patrons and clients, or culturally legitimised exchanges within vertically structured networks and communities (religious, ethnic, regional, etc.). Concomitantly, the political economy of corruption is being fundamentally transformed. Where the stakes grow exponentially through the internationalisation of illegal trade and the growing opportunities of insertion into the global market (globalisation and deregulation of the financial and commodity markets), the relationship between clients and patrons is becoming disjointed, or, more precisely, tilted in favour of the patrons. Their power is shored up by the availability of resources: the international networks, the finances, the arms to secure their influence without needing to consider their clients anymore. The line of enquiry pursued by Bayart et al. 1999 seeks to unravel trends emerging in state power and political order in Africa from a perspective of historically changing patterns and opportunities of accumulation. Here, African political structures are firmly set in an international (global) context of economic and political exchange, increasingly defined by the privatisation of former key public institutions (such as the 
customs service or organs of public security), ${ }^{98}$ by the erosion of sovereignty to International Financial Institutions such as the World Bank or the IMF as a result of severe indebtedness and the concomitant rise in influence of other, non-governmental organisations such as the Church or aid agencies (Hibou 1999). More severely for the idea of the state, based as it is on autonomy, rationality and legality, African politics are framed by a whole host of informal political, economic and military organisations (see Bayart et al. 1999).

So where does this leave the idea of political order in Africa? Can African politics only be conceptualised as kleptocratic, even felonious states? Drawing on their historical understanding of political processes, Bayart and his fellow authors are more subtle in their analysis:

Africa is resistant to every conditionality and its democratisation remains a great leap into the unknown, considering the degree to which popular sovereignty is alienated and the systematic creation of shadow networks of power is being precipitated by the privatisation of both the state and the economy. But Africa is busily recreating itself, and in this process crime is not shorn of all 'usefulness' (Bayart et al. 1999: 116).

It is the specific nature of such 'usefulness' of illegal practices that two other renowned Africanists, Chabal/Daloz (1999) emphasise in a noted study of African politics. Their line of enquiry is based on the trenchant assumption that politics in Africa derives from an instrumentalisation of political disorder; disorder that they analyse not from the perspective of institutional decay, but from the 'rational' utilisation of such informal and opaque relations by adept political actors. Their key hypothesis is the following:

In a world of disorder there is a high premium both on the vertical and personalized infra-institutional relations through which the 'business' of politics can be conducted and on access to the means of maximising the returns which the 'domestication' of such disorder requires. [Disorder] should be seen as a condition which offers opportunities for those who know how to play that system. Whether, however, such a situation is conducive to (economic and political) development as it is normally understood is a totally different question. [...] If, as we believe, there prevails in Africa a state of generalised disorder, then it behoves us to explain how such disorder is instrumentalized politically (Chabal/Daloz 1999: xix).

98 For a detailed study on the links between privatization, corruption and patronage of the era see Tangri 1999 . 
Chabal/Daloz argue extensively the fact that formal, 'modern' political norms in Africa have not succeeded to supersede other (ethnic, factional, nepotistic) modes of order and exchange within the community. However, this is not to say that African socio-political practices are traditional or primordial, or that politics organised along neo-patrimonial lines are but a stage away from 'modern' politics, but that Africa is acting according to its own developmental logic, a modernisation sui generis. Political order and political representation is maintained and reproduced through networks of patronage, not through systems of merit; hence, corrupt practices are politically not only accepted, but imperative for political success. As the authors expound: "Given the durability of vertical social relations and the endurance of certain forms of political representation, corruption remains instrumentally rational" (Chabol/Daloz 1999: 103). More to the point, they raise the question "whether such complex informal arrangements, such as well-organized predatory networks, do not actually conspire to create and maintain a system of legitimization based on unequal exchange which lies at the very heart of the political order" (Chabal/Daloz 1999: 103).${ }^{99}$ In other words, here corruption-in the sense of particular (patrimonial) modes of accumulation and (re)distribution-becomes the norm of political practice, the key logic linking political legitimacy to economic distribution, where the analysis of corruption is radicalised through the prevalence of disorder and lurking violence. Corrupt practices, in this reading, are dangerously close to the edge, serving to reproduce a political order that oscillates precariously between socio-cultural legitimacy and a sense of just economic redistribution mechanisms on the one hand, and naked power and coercion that is disembedded from any moral authority on the other.

By provocatively emphasising the 'own' developmental logic of African politics, they refuse to provide an analytic frame of reference for political dynamics of change-although under the condition of the informalisation of the state and the instrumentalisation of politics, nearly all (outwardly non-political) practices become political. Although they observe generalised features of African politics, these politics are not conceptualised in the conventional sense of 'public power' or the relationship between state and society (the 'public' and the 'private'), but in the sense "in which political actors, within both 'state' and 'civil society', link up to sustain the vertical, infra-institutional and patrimonial networks" (Chabal/

99 See also Chabal 1992 discussing the genesis of this phenomenon more extensively. 
Daloz 1999: 22). ${ }^{100}$ As Chabal/Deloz demonstrate at length, political order in Africa is not only defined by specific exchange relationships framed by instrumental rationalities sui generis, but is also inextricably caught up in them. In their view, political order in Africa is framed by a complex matrix of dependence and survival on the one hand, and profit and power on the other hand, suffused by (appropriated and adapted) spiritual, cultural, and not least legal-administrative values - and corruption is the medium of such exchange relationships, on a material and immaterial level.

The great merit of Chabal/Daloz is the boldness of their line of argument, shedding light on the transcending logic of political disorder in African countries. However, the authors analysis sketches a very bleak and, in its relentless historical, economic and cultural logic, rigid image of African politics locked in a steel cage of personal, particularistic and short-term interests, bearing a remarkable resemblance in all but their explicitly suspended judgement to Olivier de Sardan's 'infernal mechanism'. Although they discard the loaded notion of 'development' to conclude that "Africa is not degenerating, nor is it 'blocked', but that it is forging ahead, following its own path, although assuredly at great variance with existing models of development" (Chabal/Daloz 1999: 135), their uncompromising pursuit of the political economy of politics in Africa leads to the foreclosure of such alternative political spaces. The practical resilience of most African political orders to the governance and liberalisation paradigms ruling national and international discourses is pinpointed precisely; but pinpointed to the extent of fixing African politics to a particular, unchanging pattern. Given their ultimately apocalyptic diagnosis of the instrumentalisation of political disorder, it is, therefore, not evident what new paths African politics are forging, unless it is the perpetual reproduction of old wine in new bottles_-plus ça change, plus ça reste la même chose, one is tempted to conclude. ${ }^{101}$

Interestingly, although both Bayart's approach as well as Chabal/Daloz' offer a radical and insightful mode of thinking African politics, their prime reference of understanding African politics still remains the state-in its historical (dis)continuity, but also in its socio-cultural metamorphosis and

100 Evidently, the two key terms, state and civil society, are put in inverted commas for want of more appropriate terms that are not irrelevant and misleading when applied to African politics. In this reading, the state is not institutionalised or differentiated enough to be called a state, and civil society is too weak, fragmented and personalized to emancipate itself.

101 Chabal has provided a further analysis of politics in Africa in a recent volume (Chabal 2009), which will be discussed further down in this chapter. 
routinised methods of extraction and accumulation. Reviewing the literature on the state in Africa, of which above authors are only the tip of a prolific iceberg, it has become routine practice to put the concept of the state in Africa in inverted commas, highlighting the ineffectiveness of the African 'state' in its transformative capacity and widespread alienation from social representation. ${ }^{102}$ The semantics indicate that, involuntarily, disorder and criminalisation are indeed a 'corruption' of developmentas indeed the proliferation of corrupt practices themselves are a symptom of collapse, of "terminal damage at the macro-sociological level" (Chabal/ Daloz 1999: 138), and, instrumentally rational, leading to the "fusion of criminal and political practices" (Bayart 1999: 114). Corruption, as ever, serves as the lead to fathom the depths of disorder, even when corrupt mechanisms of political reproduction are conceived in terms of political (dis)order sui generis. Beyond merely measuring the distance between the 'real' and the 'shadow' state, changing patterns of corruption also indicate changing patterns of inclusion and exclusion, of the exercise of authority and accumulation of socio-cultural and economic resources.

The conceptualisation of corruption within a globalised cultural matrix as well as within a compelling politico-economic system magnifies the intrinsic logic of corruption in African political order: corruption is no longer a deviant political practice, but ambivalently represents the source of legitimacy and accumulation and, consequently, of power and authority, as well as simultaneously undermining and destabilising the very order it reproduces - a point sorely illustrated during the demise of 'stable' neopatrimonial states caught in a vicious circle of sapped economic resources and diminished political legitimacy. From a bird's eye view, the institutional regime of political orders has been shaped to accommodate clientelistic networks and vertical exchange relationships, which constitute the arteries of social as well as economic and political reproduction. From a worm's eye view, the exigencies of survival coupled with the 'normalisation' of corruption serve to inscribe corruption in legitimatised ties of reciprocity and solidarity. These long-term, historically grounded processes have been accelerated by the rapid transformations of the international political economy of the past two decades. The concern of development

102 Many authors have explored the nature of the African state from different theoretical reference-points; the common denominator, however, is that the state in Africa is a 'state' only with qualifying attributes. Some of the most notable contributions have coined terms such as 'quasi-state' (Jackson 1993), 'shadow state' (Reno 1997), or 'parastatehood' (von Trotha 2000). 
discourse with the institutional configuration of, first, the markets, and, secondly, the political order, highlighted the institutional deficiencies leading to rent-seeking and extortionary behaviour of patrons and elites; the subsequent remedies, however, have failed significantly in their quest for effective and accountable institutions. If anything, the structural changes induced by liberalisation and democratisation seem to have amplified the struggles about domination and accumulation rather than mediated and confined them-observable in the intensified illegal and illegitimate instrumentalisations of the public domain, manifested in the totalisation of power structures which intermesh formal and informal networks, in the privatisation of national and international resource extraction and accumulation, and in the consolidation of structural violence and physical coercion (Mbembe 2002). In a radicalised reading, one could argue that the very basis of socialisation (in Weber's sense of 'Vergesellschaftung') ${ }^{103}$ is put into question.

Where does that leave us with regard to the analysis of corruption? As tentatively proposed at the beginning of this chapter, the study of corruption allows for a probing study of the underbelly of state-society relations, maybe to a greater extent than envisaged. Corruption, or rather, in Olivier de Sardan's term, the 'corruption complex' is a key field providing insights into the topography of power and accumulation, into struggles about meanings and appropriations of legitimacy and authority. Significantly, these struggles are being carried out in sliding local, national and international spaces by a variety of social actors, where corrupt structures and practices not only shape patterns of (legal and illegal, legitimate and illegitimate) power and accumulation, but, transcending and compounding the above, the term 'corruption' is also used as a political resource providing the key to domestic and international funds and credibility.

\section{Conceptualising Corruption: The Question of Agency}

Distilling seminal contributions on political order and corruption in Africa through a more focused sociological filter, corruption can be

103 Weber makes the balance and convergence of interests the very essence of socialisation; only social agency endowed with these intentional or unintentional characteristics are defined as social relations framing socialisation (see Weber 1985: 2). Concepts such as 'necropower' developed by Mbembe 2002 or, in a less radical terminology, the 'politics of suffering' elaborated by Chabal 2009 illustrate formations of power that exercise brute predatory or calculated coercion, tearing at the fabric of socialisation. 
conceptualised as a mechanism along which inclusion and exclusion into social spheres operates. Compounded by the exigencies and dynamics of a globalised economy, the boundaries of inclusion and exclusion are informed by ambiguous social imaginaries, operating within the space of a formal state apparatus but framed by a more or less dynamic matrix of hybrid values and norms. On the level of social actors, the social constraints and individual dependencies arising from these particular modes of inclusion overall result in restricted spaces of social agency: social exclusion rather than inclusion, with African societies characterised by a lack of adaptive capacity conventionally described as vulnerability and instability on both a social and systemic level. ${ }^{104}$

And yet: stepping back from the bleak analysis of exclusion, the approach to corruption we embarked from comes back to mind, namely one which puts the political and symbolic struggles over meanings, standards and distinctions on centre state. ${ }^{105}$ In Johnston's sense, corruption is a systemic problem; but as he also observes, the very articulation of 'corruption' indicates semantic and political struggles over norms and standards, ambiguities over the meaning of corruption or rather over the propriety of political office and roles. Precisely this understanding takes us to a strikingly absent feature of the scholarly discourse on political order and corruption in Africa, namely the question of agency. All theories, whether they be informed by a socio-cultural or a more political scientific analytical framework, either ignore, neglect, or explicitly dismiss the possibility

104 This would provide an entry-point for a system-theoretical exploration of this lack of adaptive capacity of African societies, which emphasises the codes of inclusion and exclusion along differentiated functional logics. In this perspective, the success of modern societies is precisely due to the hardness (e.g. universal suffrage) and simultaneous suppleness (e.g. non-coercion) of such codes. Seminally, see Luhmann 1984; for a contribution on inclusion and exclusion in developing countries see Luhmann 1995. However, in strictu sensu fully articulated functional differentiation allows for no immediate sense of 'society' as a whole, only for participation in and at best a sense of separate subspheres.

105 This approach referenced Johnston, who conceptualises corruption "as a systemic problem having to do with the sources, uses, limits, and accountability of wealth and power" (Johnston 2004: 22). Although Johnston treats corruption classically as "the abuse of public roles of resources for private benefit," he emphasises "that terms such as 'abuse', 'public', 'private' and even 'benefit' are matters of considerable ambiguity or dispute in many societies. [...] Rather than ending the confusion over what constitutes a corrupt act, this approach puts conflicts over standards and ambiguities about the public-private distinction at centre stage" (Johnston 2004: 22/23, emphasis in original) — as touched upon in the Introduction. This approach ties in with other, more general social scientific theories conceptualising the interrelationship (rather than the dichotomy) between structures and agency, such as developed famously by Bourdieu 1990, 1977, or, more recently and for my purposes more usefully Migdal 2001. 
of agency. Addressing this gap, agency is understood as forms of action emerging from "the capability of the individual to 'make a difference' to a pre-existing state of affairs or course of events" (Giddens 1984: 14), which "logically involves power in the sense of transformative capacity" (Giddens 1984: 15). In a more sophisticated elaboration of agency, Emirbayer/ Mische stress the both the temporal embeddedness as well as the potential variability and creativity of human actions:

The ways in which people understand their own relationship to the past, future, and present make a difference to their actions; changing conceptions of agentic possibility in relation to structural contexts profoundly influence how actors in different periods and places see their worlds as more or less responsive to human imagination, purpose and effort (Emirbayer/Mische 1998: 973 ; emphasis in original). ${ }^{106}$

However, this capacity and variety of social agency to 'make a difference' (both to one's own actions as well as potentially to one's environment) is rendered invisible in studies of African politics. The bottom line of all enquiries treating corruption and political order in Africa is the question under which circumstances the 'infernal mechanism' can be transformed-and yet producing either strangely flat responses, ${ }^{107}$ or deeply pessimistic ones with regard to agents who are endowed with transformative capacity. ${ }^{108}$ Taking this proposition seriously, this raises the question whether these social and structural constraints imply in the last instance the dissolution of agency other than those already well endowed with social power, here: the elites, the strongmen, the thugs? The political dynamism that is implied (or implored?) malgré tout in their analyses ring hollow in the absence of the identification of actors and mediums that would be conducive to social change that, simply put, allows more rather than less freedom. On the contrary, the dynamics of the political order

106 For a discussion with regard to agency, politics and governance see Förster/Koechlin 2011.

107 An example discussed here is Olivier de Sardan 1999; another could be Hyden 2006 with his depiction of the necessity of a idealtypical legal-bureaucratic state and concomitant particular ethos of public administration.

108 Consider, for instance, Bayart 1999, who depicts crime as the motor of Africa's 'recreation'-although it is highly contentious whether 'regeneration' is an appropriate term for what essentially describes the tightening spiral of illegitimate and downright violent modes of inclusion/exclusion. Or consider the "systemic contradictions" that Chabal (2009: 83) identifies as binding African political authority to particularistic interests, leading to a "calculated violence of neglect" (Chabal 2009: 153) by those in power, ultimately leading to the corrosion and downright breakdown of the foundations of agency. See also Chabal 1999 or Mbembe 2002. 
carved out are stark: institutional reforms are appropriated, moulded and instrumentalised by particularistic logics; structural transformations of the economic and political regimes lead to the privatisation of political and economic power; and socio-cultural practices solidify a moral economy of corruption, locking African politics in a spiral of unravelling social order, brutalised violence and criminalised economics-leaving no space for struggles over such norms and practices. Other than on a highly generic level, the scholarly discourse fails to identify the social actors and agency conducive to shaping a political order that mediates instead of produces conflict, that provides a structured space for consensus on public purposes. 109

In other words, the academic discourse on corruption is curiously dismissive of the intentional and unintentional activities by emancipatory social forces, concentrating instead on the force (in the sense of both power and of violence) of intentional activities to produce disorder by established elites or unintentional sedimentations of exclusionary structural properties. The development discourse on corruption, on the other hand, is bound by distinct spaces of thought and action and the interrelated technocratic system of relations through which it is produced and reproduces itself.

So the elephant sits squarely in the room: Where is the locus of agency for democratic spaces? ${ }^{110}$ Against the backdrop of both the development as well as the scholarly discourse on corruption this is the key question guiding the second part of my enquiry, which will be pursued with some conceptual enrichment in the next chapter. First, however, I shall attempt to sketch an outline of the invisible but palpable elephant, which is primarily evident as that which is absent: the distinction between private and public, informal and formal. The imploration of these boundaries, however, was ever of an idealtypical nature, and is particularly ill suited to capture

109 For many others consider, for instance, Hyden, who, like Huntington 40 years earlier, observes that "Africa needs to transform its movements into political parties that are issue-oriented and focused on constructive problem solving" (Hyden 2006: 273).

110 I quite intentionally risk the over-optimism which Chabal identifies in the quest for agency in African political orders: he introduces his latest book with a critical discussion of the notion of agency as used in African studies, pointing to the analytical risk that too strong a focus on agency can lead to a neglect or whitewashing of the "systemic condition in which development is not really on the agenda" (Chabal 2009: 15). My analytical focus, however, is precisely on the role of agency in fostering democratic politics. 
contemporary processes and framings of social and political change. ${ }^{111}$ Social transformations that shape political orders and, in a metapolitical sense, the creation of regimes that are based on general, inclusive, and public-oriented justifications, rather than particularistic and exclusionary logics are highly complex and contextualised both in space and time-and increasingly so in a world characterised by deterritorialisation, in which globalised economic, social, political and cultural relationships cut across national and local topographies. As a critical reading of both the development discourse as well as the scholarly discourse on corruption and political order in Africa shows, the imploration of a transformative deus ex machina is fraught with theoretical and empirical difficulties. Hence, the identification of such emancipatory struggles requires an analytical shift. A case will be made here for linking the macro-level of analysis, such as expounded both in the political economic theories as well as in the more socio-culturally informed theories on corruption and political order, with a micro- and meso-level perspective, analysing the socio-cultural constraints and political spaces from the viewpoint of particular social actors. Taking articulations of 'corruption' as a pars pro toto, how and why are patterns of structuration and institutionalisation of norms and practices shaped, which social struggles and social actors gain traction, which structural properties are iterated and solidified, and which are marginalised and vanish, shaping orders of inclusion and exclusion?112

To understand how political orders emerge which allow for communities of interest to negotiate their differences, and, in a more normative twist, develop a fundamental readiness to moderate parochial or individual

111 For theoretical contributions and case-studies on the blurring of the public-private boundaries see Peters et al. 2009; for a consolidated interdisciplinary approach see Peters/ Koechlin/Zinkernagel Fenner 2009 and Peters/Förster/Koechlin 2009.

112 What is referred to here is the structuring of social relations in Giddens' sense, which involves the "patterning of social relations in time-space involving the reproduction of situated practices" (Giddens 1984: 17). In other words, structures are not exogenous, they emerge from situated practices of human agents. Subsequently, Giddens defines structure in contrast to functionalist or system-theoretical notions: "I treat structure, in its most elemental meaning at least, as referring to such rules (and resources). It is misleading, however, to speak of 'rules of transformations' because all rules are inherently transformational. Structure thus refers, in social analysis, to the structuring properties allowing the 'binding' of time-space in social systems, the properties which make it possible for discernibly similar social practices to exist across varying spans of time and space and which lend them 'systemic' form” (Giddens 1984: 17). 
interests in consideration of some common good, ${ }^{113}$ a new dimension needs to be incorporated into the analysis that has only been alluded to hitherto: namely the emergence of public spheres. Put in a nutshell, the particularly Western trajectory has been the substitution of physical violence with the force of discursive argument in specific public spheres and institutions, opening up historically unprecedented spaces for agency, for intentional and self-reflected social action.

Here the normative precedence of politics comes into play when thinking about modes of inclusion that go beyond mere systems and structures to include values and symbolic orders. This brings us back to Leys' emphasis on, in his terms, 'public morality' (Leys 1965) in his discussion of corruption in African states. As Philp stresses in an essay on political corruption, "politics is partly about the contestation and projection of conceptions of the public interest. [...] Public office and public interest are, then, intimately connected" (Philp 1997: 445). He fleshes out the distinctive feature of politics (as opposed to other exchange systems or social relations) as being "the type of general, public orientated justification used to legitimate its claims" (Philp 1997: 451). In other words, politics are necessarily tied to constitutions of legitimacy and representation. This has direct repercussions on the notion of what constitutes a public good. It also reframes the problem of corruption:

Politics takes normative precedence because it orders otherwise irresolvable forms of social and interpersonal conflict [...]. It is impossible not to recognize that political authority can be exercised cruelly, violently, or vindicatively, or that those who rule may do so incompetently. In each case, these activities will damage the capacity of the authority to secure a stable order of rule capable of resolving conflict. But political corruption is distinctive as a form of dereliction: if political authority is desirable because it orders fundamental conflicts between interests, the suborning of that authority to serve one particular set of interests covertly reinstitutes the domination which that authority is designed to avoid (Philp 1997: 453).

What is outlined here are two sets of questions. The first set revolves around a political system which allows for the ordering and mediation of divergent and possibly antagonistic interests; a political system which orders difference without intolerable suppression or exclusion. The second set revolves around the mechanisms, deliberative or other, that

113 This is strongly based on Shils concept of 'civility', i.e. the consideration toward 'the other' beyond one's family or own community (see Shils 1991). These are concepts that we shall return to further down. 
define public interests. What is collectively desirably? ${ }^{114}$ Precisely the discourses and articulations around such ethical notions, around desirable public goods and the emergence of and internalisation of values that inform them are the hallmarks of the public sphere as understood here. With corruption subverting and appropriating procedures and values that characterise such a deliberative public sphere, African societies are, again, characterised by the absence of such a public sphere. And evidently it would be a gross naïvety to transport notions of a deliberative and procedurally 'pure' public sphere to any reality, but in this case in particular to African topographies characterised by exclusionary fields of power and a vast array of social imaginaries.

A key issue is precisely the framing of such deliberative spheres and processes. Chabal, for instance, based on his analysis of the hybrid concepts shaping legitimacy in African politics, diagnoses the 'systemic' impossibility of the emergence of such public ethics: "Therefore, the diffculty lies less in the inherent corruption of political leadership in Africahowever acute that may be-than in the systemic contradictions inherent in the translation of the local ethics of public virtue into a more coherent, national and long-term vision of the public good" (Chabal 2009: 83-84). This is a point made already in the seminal work of Peter Ekeh, who cuts across Weberian distinctions with his conclusion that Africa has not one but two public spheres, each one characterised by different 'moral linkages' to the private realm: the primordial public realm is a sphere characterised by communal relationships and values, whereas the civic public realm is the political and administrative structure historically associated with the colonial state. The public sphere that he accords moral primacy to is, perhaps surprisingly, not the civic public realm, which he sees as historically perverted: "The civic public in Africa is amoral and lacks the generalized moral imperatives operative in the private realm and in the primordial public" (Ekeh 1975: 92). The moral primacy lies in the 'private' realm, or perhaps more aptly termed a non-official public - but this private realm is informed by a cultural matrix disjoined from the norms of the political system it operates in. So how to achieve these seemingly

114 Seminally on deliberative mechanisms and constitutions of the public sphere, see Habermas' influential theory of communicative agency and the public sphere (Habermas 2009a [1962], 2009b [1982]). As Chabal puts it with regard to African societies: "To what main aims should socio-economic or political agency be directed? The pursuit of public goods is, in every society, the mark of political legitimacy" (Chabal 2009: 81). 
intractable translations of values and norms, ${ }^{115}$ in the sense of collective understanding towards some common good, and of a public sphere that enjoys moral legitimacy?116

The discussion on post-colonial African states has demonstrated how differing African trajectories are, with corruption as a structuring property, with structural and physical violence characteristically removed from social legitimacy, and subsequently public spheres shrinking into private or covert spaces. And yet: the pervasiveness of corruption and the corollary straddling and fusion of spheres characterising African political orders still do allow for the emergence of public spaces and procedures for transacting different interests, albeit in spaces and institutions that may not correlate to conventional definitions of the public sphere. ${ }^{117}$

On centre stage is the question how the systemic condition of exclusion can be transformed into a systemic condition enabling inclusion(s) or, put in more political terms: into structuring properties of the political order enabling emancipation, of creating spaces for the negotiation of societal meanings, the mediation of particularistic and competing interests. ${ }^{118}$ This puts the scholar of African politics doubly on the spot: Whence the social agents articulate and resourceful enough to transform prevailing power relations? And of course, which ideas and values inform social practices and actions that are indeed conducive to an emancipatory political order?

This is an essentially political quest, and the objective of my analysis is precisely to reinsert the political back into a theory of African political

115 Conventional dichotomies capture such translations in terms of transformations from local to national, from informal to formal, from private to public. Given the inherently problematic content of these terms, I prefer to formulate the process in more open terms.

116 There is a caveat with regard to the pairing of these seeming dichotomies: 'local' does not necessarily imply 'informal', or 'national' equal 'formal', etc. This is a trap that, for instance, Chabal 2009 seems precariously close to, who routinely implies a synonymous relationship between 'traditional' and 'local', even if the translation of such 'localities' does lead to a political (dis)order suigeneris.

117 For a highly insightful case-study on articulations of a public sphere and moral discourse in Sierra Leone during the 1986 elections see Ferme 1999.

118 Although Geertz emphasises the symbolic dimension, he infers the importance of ideas and their transformation into values, norms and material substance through social action: "Ideas_religious, moral, practical, aesthetic_must, as Max Weber, among others never tired of insisting, be carried by powerful social groups to have powerful social effects; someone must revere them, celebrate them, defend them, impose them. They have to be institutionalized in order to find not just an intellectual existence in society, but, so to speak, a material one as well" (Geertz 1993: 314). 
order. To achieve this, a last conceptualisation of corruption is required, before moving on to a detailed empirical discussion of such potential social forces. In the next chapter, I undertake a conceptualisation linking 'corruption' to social agency and social articulation. Here, corruption is seen neither as social practice nor structural feature, but through the very lens of emancipation: as a discursive representation that creates the possibility of public spaces and discursive interaction.

\section{Conclusions: Corruption, (Dis)Order and Agency}

The second discourse I portrayed is the scholarly discourse on corruption. Although this second discourse may not be as powerful in material terms as the development discourse, it produces related categories of thinking about corruption and hence about 'right' and 'wrong', or 'conceivable' and 'inconceivable' frames of political order and social organisation. As a body of structuring principles the scholarly discourse contributes to the formation of social facts, social facts which inform and are informed by the way we think and perceive of 'corruption'. ${ }^{119}$ Within this discourse corruption is conceptualised in a more multi-faceted way, illuminating structures, practices, norms and cultural matrixes informing and defining 'corruption'. What, however, is systematically squeezed out is the possibility of agency and mobilisation, the possibility of challenging dominant socio-political imaginaries and, in Bourdieu's sense, of dominant positions within the social space. In short: the scholarly discourse dispossesses African political orders of actors, fields and practices of political struggle that could or do lead to a 'viable social order', ${ }^{120}$ a social order which is politically permeable to social negotiation and procedurally firm enough to protect social spaces.

The separation of the two discourses is an analytical sleight of hand to render the respective contours more visible. However, it is clear that the two discourses are interrelated and mutually inform and shape each other in manifold ways. They are both, to put it in Escobar's terms, part "of an institutional field from which discourses are produced, stabilised,

119 See Durkheim 2002 for his seminal theory on social facts; for a first seminal contribution on the role of epistemology to discourse theory see Foucault 1966, which also informs the post-development approach. See also Bourdieu 1985 for a succinct discussion of the relationship between objective power relations and categories of the social world.

120 This is a term borrowed from Laclau (1996: 19, endnote 2) although I do not use it in precisely the same sense as he does. 
modified, and put into circulation", constituting "an apparatus that organizes the production of forms of knowledge and the deployment of forms of power, relating one to the other" (Escobar 1995: 46). Most obviously, the scholarly discourse provides the epistemology, the legitimisation of terms and concepts, the categories and taxonomies, which the development discourse appropriates and applies in its intervention strategies. It legitimises and justifies the expert knowledge that development professionals 'apply', that policies and strategy papers are based on. On the other hand, development agencies provide a substantial flow of funds to communicative platforms and academic research exploring governance, actively fostering scientific knowledge creation and knowledge diffusion that ultimately validates and legitimises 'right' concepts and interventions.

These linkages consolidate the strategic apparatus ${ }^{121}$ fusing the symbolic imaginary and epistemic communities with the material resources, woven together by a myriad of social and systemic threads that serve to render the distinctions between the two discourses a matter of focus. One remarkable feature of the corruption discourse in this wider sense is precisely its ability to absorb and render intelligible a multitude of different and even antagonistic elements, even where theoretical and practical contestations about the 'right' way of seeing and doing are made audible and visible. ${ }^{122}$ This resilience to deconstruction is part of its adaptive strength - which is derived from systemic logics that actively produce and require legitimising factors and knowledge for new interventions, new research, new policy-work. Although one might assume that trenchant critique of the discourse constitutes an impossible inscription, by undermining the very configurations and mechanisms of the discourse on corruption, such counter-representations are mostly acknowledged 'constructively'. This holds especially true for scholarly critique, which is mandated by the development industry and forms part of the image and

121 See Foucault 1966.

122 Interesting examples are provided by (former) development workers who critically dissect the mechanisms of development cooperation that themselves are the precondition for (often: large-scale) corruption to emerge and solidify into permanent practices. For a detailed deconstruction of the corruption system within a programme, written up by the former programme manager, see Jansen 2009 who feeds his knowledge back into the discourse through an institution established by the very industry he is deconstructing. For a trenchant critique of World Bank lending practices and the window-dressing with regard to corruption see Berkman 2008. For classic critiques, including the systemic (at best unintentional) fostering of mismanagement and bad governance of foreign aid see Kabou 1993, Hancock 1994, Hanlon 1996, Raffer/Singer 1996, Lancaster 1999, Easterly 20o6, or Moyo 2008. 
symbolic representation of reflexive, self-critical development agencies. In this way such critique actually paves the way to the adaptation and modification of the discourse, whose reproductive rationale is ultimately even strengthened-as witnessed, for instance, in the governance turn of the development discourse in the wake of singularly failed market-centred development interventions. ${ }^{123}$

So summing up, the hegemonic formations that the double discourse on corruption consolidates, especially in its categorisation ${ }^{124}$ of African political orders, has lead to an impasse in identifying and understanding loci and agents of change beyond conventional, generalised spaces. In the scholarly discourse, potential agents and spaces of change are dismissed as inexistent, powerless or appropriated by dominant rationales of 'corruption', extraction and disorder. The development discourse, by its essentially bureaucratic nature, merely identifies such agents in a highly technocratic way-the usual suspects in civil society or the private sector, that, however, disappear behind the mechanics of the project implementation cycle and programme implementation. Even where development agencies seek more sophisticated approaches which capture the politics of development, such as for instance in the concept of 'drivers of change', 125

123 There are exceptions, of course, where such critique oversteps the boundaries of the discourse. See, for instance, the example of Sir Edward Clay, at the time British ambassador to Kenya, who in a speech to the British Business Association in Nairobi in 2004 accused the Kenyan government under Mwai Kibaki of being on a 'looting spree' characterised by arrogance and greed. He famously exclaimed that "their gluttony causes them to vomit all over our shoes" (http://www.independent.co.uk/opinion/commentators/ edward-clay-kenyas-government-is-full-of-corrupt-gluttons-553304.html; last accessed 25 March 2010). Although the EU did later that year freeze $£ 83$ million because of major corruption scandals, in particular the Anglo-Leasing scandal (see http://www.guardian.co.uk/ world/2004/jul/22/eu.kenya; last accessed 25 March 2010), Clay was later disowned by the British government (for a rendition see Wrong 2009). For examples of the World Bank's blinkering-strategies see Berkman 2008.

124 The discourse on corruption, intentionally or not, has a strong element of 'shaming' of agents and structures of African political orders involved, be it rapacious elites or specific socio-cultural matrices. This corresponds neatly to Bourdieu's statement on the power of categorisation and the entymology of the word: "In fact, this work of categorization, i.e. of making-explicit and of classification, is performed incessantly, at every moment of ordinary existence, in the struggles in which agents clash over the meaning of the social world and their position within it, the meaning of their social identity, through all the forms of benediction or malediction" (Bourdieu 1985: 729).

125 This is a concept developed by DFID in their attempt to identify actors and institutions that are practically more relevant to initiating and supporting governance reforms. Some of the Drivers of Change country reports are some of the best analyses of the political economy. However, ultimately operational rationale derives from precisely the same technical reduction which it seeks it overcome: its success is not measured in terms of revealing and addressing repressive politics or skewed accountability processes, its success 
the practices sur place of the Anti-Development Machine described so intricately by Ferguson (1990) pulverise the political to fit the operational logic of development cooperation.

In contrast, the premise of this chapter is that tropes of change and political imaginaries do indeed exist in African political orders. Not only do they exist; my key hypothesis is that the very discourse of corruption provides the terrain in which these struggles take place. The overarching interest and the main objective of the following chapters is, consequently, the exploration of the political and social spaces that 'corruption' opens up (or closes down), i.e. the manifold political and social articulations that feed off corruption as a reference. My premise is that although the discourse of corruption may take on a hegemonic (in the sense of dominating) shape, it actually provides the terrain for the articulation of particular struggles - and potentially may lead to the creation of a plurality of political spaces and public spheres.

is measured in terms of the 'tools' and 'training programmes' which it has allowed DFID to produce (see DFID 2004). 